\title{
A Review of Mixed Methods Community-Based Participatory Research Applications in Mental Health
}

\author{
David E. Jones, EdD \\ Liberty University, Lynchburg, Virginia, United States \\ (iD https://orcid.org/0000-0001-5040-1708 \\ Robin Lindquist-Grantz, $\mathrm{PhD}$ \\ University of Cincinnati, Cincinnati, Ohio, United States \\ Melissa DeJonckheere, $\mathrm{PhD}$ \\ University of Michigan, Ann Arbor, Michigan, United States \\ Contact: $\underline{\text { dejones14@liberty.edu }}$
}

\begin{abstract}
The aim of the paper was to methodologically review the intersection of mixed methods research (MMR) and community-based participatory research (CBPR) in the field of mental health research. We classify this intersecting approach as MMCBPR. The methodological review of empirical literature was conducted between October 2017 and March 2020 of full-text articles in Scopus, Pubmed, ProQuest Central, Web of Science, and EBSCOhost search engine databases in the English language. Twenty-nine studies meeting the inclusion criteria were included in the final analysis. We found some evidence of MMCBPR but it was limited by factors such as a lack of explicit rationales for the use of MMR and CBPR, limited evidence of long-term commitment to a community, and an ad hoc approach to the application of MMR and CBPR. These findings informed the development of practical recommendations for psychologists, mental health professionals, and researchers in the application of MMCBPR. In particular, our MMCBPR recommendations aim to advance the social justice agenda in counseling psychology, increase the rigor of MMCBPR approaches in mental health studies, and inform how advanced mixed methods applications can be used to address the complexities associated with mental health and well-being.
\end{abstract}

Keywords: mixed methods research; community-based participatory research; mental health; social justice; psychology; counseling

Date Submitted: June 22, 2020 | Date Published: December 7, 2020

\section{Recommended Citation}

Jones, D. E., Lindquist-Grantz, R., \& DeJonckheere, M. (2020). A review of mixed methods community-based participatory research applications in mental health. Journal of Social, Behavioral, and Health Sciences, 14, 254-288. https://doi.org/10.5590/JSBHS.2020.14.1.18

Correspondence concerning this article should be addressed to David E. Jones, Assistant Professor, Department of Counselor Education and Family Studies, 1971 University Blvd., Lynchburg, VA 24515; 513.427.2575; dejones14@liberty.edu. Declaration of Interest Statement: The authors declare that they have no known competing financial interests or personal relationships that could have appeared to influence the work reported in this paper. Declaration of Funding: This research did not receive any specific grant from funding agencies in the public, commercial, or not-for-profit sectors. 
Jones et al., 2020

\section{Introduction}

Estimates of mental health and substance use indicators demonstrate that the rates of people living with these disorders are increasing. For example, in the United States in 2017, an estimated 46.6 million adults aged 18 or older had "any mental illness" and 11.2 million had a "serious mental illness," both of which were a higher percentage of adults than most of the previous decades (SAMHSA, 2018). The same study found that approximately 19.7 million people in the United States aged 12 or older had a substance use disorder (SAMHSA, 2018). Additionally, adolescent and adult suicide rates have been on the rise in nearly all states, with 25 states seeing rate increases of more than 30 percent (National Center for Health Statistics, 2018). These trends are also reflected in worldwide estimates where the mental illness burden has increased by $37.6 \%$ from 1990 to 2010, and mental illness and substance use disorders were the leading cause of years lived with a disability (Whiteford et al., 2013).

Mental illness and substance use disorders are pervasive across age, race, ethnicity, gender, and geography; however, research has shown that a number of risk factors are associated with these mental health concerns. Some of these include but are not limited to healthcare access, food security, housing stability, environmental health, and crime rates (Jones et al., 2017; Lake \& Turner, 2017; Silva et al., 2016), as well as documented racial and ethnic disparities (American Psychiatric Association, 2017). With so many potential risk factors and rising prevalence of mental illness and substance use disorders, communities and health systems are increasingly overwhelmed (Whiteford et al., 2013). Furthermore, many in the mental health field are experiencing disillusionment with traditional approaches of research that do not sufficiently solve real-world problems nor harness the expertise of the individuals directly impacted (Hanson et al., 2005; Minkler \& Wallerstein, 2008). Thus, psychologists and other mental health practitioners have called for more robust methodologies, including methodological pluralism, that holistically address these complex issues (Fine, 2007; Gelso, 1979; Hanson et al., 2005; Haverkamp et al., 2005; Mertens et al., 2016; Palinkas et al., 2011). Moreover, as the psychology field pushes to actualize social justice principles to address disparities associated with mental and emotional well-being (Scheel et al., 2018), there is a need to examine the methodologies of studies that have aimed to incorporate a social justice.

\section{Mixed Methods and Community-Based Participatory Research}

Mixed methods research (MMR) has become an established methodological approach that integrates quantitative and qualitative methods throughout all phases of a study. It has been called the third wave of research with the first wave being quantitative and the second wave qualitative (Christ, 2013). Scholars have written about how the approach is particularly suited to studying complex phenomena within communities because it capitalizes on the benefits of quantitative and qualitative methods for a more comprehensive examination (Badiee et al., 2012; Creswell et al., 2011; Mertens et al., 2016; Teddlie \& Tashakkori, 2009). As scholars work to further develop the methodology, advanced applications that combine MMR with other research approaches, such as experimental designs and program evaluation, are being used and studied (Creswell, 2015; Creswell \& Plano Clark, 2018; Plano Clark \& Ivankova, 2016). One such advanced application is the intersection of MMR and community-based participatory research (CBPR), which has been referred to as MMCBPR (DeJonckheere et al., 2018).

CBPR is an approach to research that aims to maximize the expertise of all stakeholders throughout every phase of research (Minkler \& Wallerstein, 2008). Proponents of CBPR argue that the approach is more culturally relevant to focal populations than traditional positivistic research approaches and, therefore, can be more rigorous (Balasz \& Morello-Frosch, 2013; Vaughn et al., 2017). CBPR has specifically been commended as a viable approach to improve complex mental health concerns (Anderson-Lewis et al. 2012) and in substance abuse prevention and intervention (Allen et al., 2013; Jumper-Reeves et al., 2014). Moreover, CBPR is an approach that connects with the core values of counseling psychology and the attributes desired in 
students and practicing psychologists. This includes attending to self-actualization, not only of client but of communities, attending to the call of social justice, and a strength-based approach (Minkler \& Wallerstein, 2008; Scheel et al., 2018). Because CBPR is an orientation to research, it is paired with other methodologies and research designs to promote community-driven research questions and solutions.

As the use of MMR and CBPR increases in the health and social-behavioral sciences (Israel et al., 2013; Minkler \& Wallerstein, 2008), so does their pairing as both a methodology and a practice for equitably engaging communities in research and problem-solving. In particular, the combination of CBPR and MMR is advocated for when working with vulnerable populations (Johnson \& Shipp, 2009; Lucero, Wallerstein et al., 2018; Windsor, 2013). In a methodological review of 129 MMCBPR studies, DeJonckheere et al. (2018) found a rise in the use of MMCBPR in the past decade, with most of the studies investigating issues affecting marginalized and vulnerable populations. The authors concluded that further study of MMR and CBPR as an intersecting approach within specific fields is needed in order to fully understand the use and utility of MMCBPR as a methodological practice. As cited in their article, one of the top fields for the application of MMCBPR was "behavioral health," which included mental health and substance use ( $15 \%$ of the articles).

The increased prevalence of mental health issues worldwide and the growing need for research that has both scholarly and practical applications warranted thorough evaluation of MMCBPR in mental health. In conducting this methodological review, we examined how MMR and CBPR intersect in existing empirical studies of mental health in order to inform future research methodology. The purpose of the review was to:

1. Describe the current use of MMCBPR in the field of mental health;

2. Critique the observed application of MMCBPR in mental health;

3. Offer recommendations for effective application of MMCBPR.

\section{Methods}

\section{Study Selection Criteria and Search Strategy}

Our methodological review included peer-reviewed empirical studies in the English language offered as fulltext articles in the search engine databases (Scopus, Pubmed, ProQuest Central, Web of Science, and EBSCOhost). Our searches took place between October 2017 and March 2020. We defined each journal article as its own "study," such that evidence published in related articles was not included unless it also fit the selection criteria. We applied the following search criteria ("community based participatory research") AND ("mixed-method*" OR "mixed method*”) AND ("qualitative") AND (“quantitative") AND (("mental health") OR ("behavioral health”) OR ("substance abuse”) OR ("substance use”) OR ("psychological symptomatology ") OR ("psychological distress") in the academic databases. Our search criteria included the MMCBPR fields used by DeJonckheere et al. (2018) in their methodological review and added fields related to mental health to expand their criteria and capture articles beyond their findings. We excluded reviews, conference proceedings, gray literature, theses, book chapters, protocols or study design proposals. We only included studies that explicitly used the term CBPR, excluding other similar approaches such as action research, participatory action research, and citizen science because of the primary use of CBPR in health-related fields. For the mixed methods criteria, articles needed to include both qualitative and quantitative data collection and analysis in the same article. Due to the nature of the study design, an IRB review was not required. 


\section{Data Extraction and Synthesis}

For the review, we adopted the procedures used by DeJonckheere et al. (2018) and adapted an extraction table and a codebook with operational definitions for both MMR and CBPR and the intersection of the two approaches (Table 1).

Table 1: Definitions Table

\begin{tabular}{|c|c|}
\hline Category & Description \\
\hline Empirical Study & $\begin{array}{l}\text { Is the article an empirical study (including experiments, interventions, } \\
\text { assessments, and evaluations)? }\end{array}$ \\
\hline Mental Health & $\begin{array}{l}\text { Does the study content focus on issues related to mental health, such as } \\
\text { symptomatology, trauma (e.g. child neglect/abuse), substance use, stress, } \\
\text { resilience, etc.? }\end{array}$ \\
\hline Topic & What is the overall content area for the study? \\
\hline Focal Population & Are youth and/or adults the primary target population being studied? \\
\hline Study Participants & $\begin{array}{l}\text { What is the specific population being studied (e.g. immigrants, elderly, } \\
\text { domestic violence survivors, Latinos, etc.)? }\end{array}$ \\
\hline Geography & $\begin{array}{l}\text { In what geographic setting does the study take place? (e.g. urban, rural, } \\
\text { suburban) }\end{array}$ \\
\hline Location & Enter country/location within United States. \\
\hline Study Purpose & What are the methodological aims or goals of the study? \\
\hline MMR Approach & Does the study include both quantitative and qualitative data collection? \\
\hline MMR Design & $\begin{array}{l}\text { What type of MMR design was used in the study (concurrent; explanatory } \\
\text { sequential; exploratory sequential; multistrand/multiphase; intramethod)? }\end{array}$ \\
\hline MMR Rationale & $\begin{array}{l}\text { What is the stated purpose for incorporating both quantitative and } \\
\text { qualitative data? }\end{array}$ \\
\hline $\begin{array}{l}\text { Quantitative } \\
\text { Methods }\end{array}$ & What quantitative methods were used? \\
\hline $\begin{array}{l}\text { Qualitative } \\
\text { Methods }\end{array}$ & What qualitative methods were used? \\
\hline MMR Language & $\begin{array}{l}\text { Was MMR language explicitly used to describe the study or provide a } \\
\text { rationale? }\end{array}$ \\
\hline MMR Reference & $\begin{array}{l}\text { Did the authors include explicit references to MMR methodological } \\
\text { citations? }\end{array}$ \\
\hline $\begin{array}{l}\text { MMR Integration } \\
\text { at Methods Level }\end{array}$ & $\begin{array}{l}\text { What approach(es) were used to integrate the methods used (connecting, } \\
\text { building, merging, embedding)? }\end{array}$ \\
\hline $\begin{array}{l}\text { MMR Integration } \\
\text { at Interpretation } \\
\text { Level }\end{array}$ & $\begin{array}{l}\text { What approach(es) were used to integrate the interpretation and reporting } \\
\text { of quantitative and qualitative data (narrative; data transformation; joint } \\
\text { display)? }\end{array}$ \\
\hline
\end{tabular}




\begin{tabular}{|c|c|}
\hline Category & Description \\
\hline CBPR Approach & Does the study use the term Community-Based Participatory Research? \\
\hline CBPR Rationale & What is the rationale for using a CBPR approach? \\
\hline CBPR 9 Principles & Which CBPR principles were represented in the article? \\
\hline CBPR Partners & What types of community partners were included in the study? \\
\hline $\begin{array}{l}\text { Intersecting } \\
\text { Evidence }\end{array}$ & $\begin{array}{l}\text { "Intentionally embedding, or joining of two or more research designs, } \\
\text { methodological approaches, and/or theoretical frameworks within a study's } \\
\text { mixed methods research design" (Plano Clark \& Ivankova, 2016, p. 137) } \\
\text { - Did the article indicate evidence of intersecting MMR and CBPR? } \\
\text { - How did the authors describe the intersecting of MMR and CBPR? }\end{array}$ \\
\hline $\begin{array}{l}\text { Phase of MMR in } \\
\text { CBPR Cycle }\end{array}$ & $\begin{array}{l}\text { What CBPR phase is described in the paper? May or may not be explicitly } \\
\text { stated. }\end{array}$ \\
\hline $\begin{array}{l}\text { Benefits of } \\
\text { Intersecting MMR } \\
\& \mathrm{CBPR}\end{array}$ & $\begin{array}{l}\text { Does this paper discuss the benefits of MMCBPR intersectionality? If so, } \\
\text { what was stated? }\end{array}$ \\
\hline $\begin{array}{l}\text { Challenges with } \\
\text { MMCBPR }\end{array}$ & What are the stated challenges of employing MMR and CBPR? \\
\hline
\end{tabular}

For MMR, we included studies that described both qualitative and quantitative approaches in the same empirical article, even if they did not call their approach "mixed methods." Specifically, a study was labeled as MMR if it described both qualitative and quantitative data collection, analysis, and results. MMR study designs were defined based on Creswell \& Plano Clark's (2018) definitions (exploratory sequential, explanatory sequential, convergent and multistage). A fifth approach, intramethod designs (Johnson \& Turner, 2003), was included based on prevalence in MMCBPR studies (DeJonckheere et al., 2018). Integration, a core component of mixed methods designs that refers to the intentional mixing of qualitative and quantitative approaches, includes integration through methods (connecting, building, merging, and embedding) and reporting (weaving, data transformation, and joint displays; Fetters et al., 2013).

Finally, we used the nine CBPR principles offered by Israel and colleagues (2013) to operationalize when reviewing each article-(1) recognizes community as a unit of identity; (2) builds on strengths and resources within the community; (3) facilitates a collaborative, equitable partnership in all phases of research, involving an empowering and power-sharing process that attends to social inequalities; (4) fosters co-learning and capacity building among all partners; (5) integrates and achieves a balance between knowledge generation and intervention for the mutual benefit of all partners; (6) focuses on the local relevance of public health problems and on ecological perspectives that attend to the multiple determinants of health; (7) Involves systems development using a cyclical and iterative process; (8) disseminates results to all partners and involves them in the wider dissemination of results; and (9) involves a long-term process and commitment to sustainability.

The initial search resulted in 964 articles. We reviewed and removed articles meeting the exclusion criteria: conference proceedings $(n=70)$, systemic reviews or study protocols, $(n=293)$, non-English $(n=2)$, and duplicates $(n=78)$. We then examined the remaining articles $(n=521)$ using the data extraction table and codebook criteria. Initially, the first 40 articles were analyzed collectively by all team members. Following an independent review of an article, the team discussed the rating (accepted, rejected, or needs further 
discussion) of each article. This was an iterative process. For example, the first three articles were reviewed by the team and examined for rater reliability as well as consistency of the codebook criteria. We then reviewed the next three articles collectively to further verify rater reliability and codebook consistency. For articles needing further discussion, all team members jointly discussed and reviewed each article to arrive at a consensus on status based on the codebook criteria. We then divided the remaining articles between the research team members for independent review. The process continued iteratively for the remaining articles with biweekly to monthly team meetings to discuss the articles that were independently reviewed. After the review process, 29 articles met the full criteria.

\section{Results}

\section{Study Sample Characteristics}

The 29 articles' years of publication ranged from 2008 to 2020 (Table 2). Our study topics included youth psychotropic medications, bipolar disorder, substance abuse, bullying, exercise, mental health stigma, stress, trauma, obesity, parenting, Latina mental health, transgender, cultural adaptation of mental health interventions, and care coordination effectiveness. The study focal populations were adults $48 \%(\mathrm{n}=14)$, youth $24 \%(n=7)$, and both adults and youth $28 \%(n=8)$. The geographical distribution was $69 \%(n=20)$ in the United States and the other 31\% $(\mathrm{n}=9)$ in Canada, New Zealand, Zambia, and South Africa. The majority of the studies took place in urban settings $76 \%(\mathrm{n}=22)$. Participants included racial/ethnic minority groups $35 \%(n=8)$; individuals experiencing mental illness 20\% $(n=8)$; healthcare service providers $20 \%(n=7)$; caregivers 10\% $(n=5)$; school personnel 10\% $(n=4)$, and individuals experiencing homelessness, parolees, and community members $10 \%(\mathrm{n}=3)$. Some studies included more than one type of participants; therefore, the total percentages may be greater than 100. For example, Ford-Paz and colleagues (2019) conducted a study of a school-based intervention with program youth, program counselors, school staff, and parents as participants. 
Table 2: Study Characteristics

\begin{tabular}{|c|c|c|c|c|c|}
\hline Study & Topic & $\begin{array}{l}\text { Target } \\
\text { Population }\end{array}$ & Geography/Location & Study Participants & Study Purpose \\
\hline $\begin{array}{l}\text { Barnett et } \\
\text { al., } 2018\end{array}$ & $\begin{array}{l}\text { Psychotropic } \\
\text { medications for } \\
\text { youth in child } \\
\text { welfare }\end{array}$ & Youth & Rural/USA & $\begin{array}{l}\text { Child welfare staff, } \\
\text { mental health } \\
\text { professionals }\end{array}$ & $\begin{array}{l}\text { To establish a local stakeholder advisory team } \\
\text { that will assist in the development of a } \\
\text { psychotropic field guide for children in welfare } \\
\text { and run a pilot test. }\end{array}$ \\
\hline $\begin{array}{l}\text { Bell et al., } \\
2014\end{array}$ & Bullying & Youth & $\begin{array}{l}\text { Lumbee Tribe/ } \\
\text { Rural/North } \\
\text { Carolina, USA }\end{array}$ & $\begin{array}{l}\text { American Indian } \\
\text { youth }\end{array}$ & $\begin{array}{l}\text { To examine the perceptions and demographic, } \\
\text { health, and psychosocial correlates of bullying } \\
\text { among Lumbee Indian youth in North Carolina }\end{array}$ \\
\hline $\begin{array}{l}\text { Berkel et al., } \\
2013\end{array}$ & $\begin{array}{l}\text { Adolescent } \\
\text { substance use \& } \\
\text { sexual risk behavior }\end{array}$ & Adults & Rural/Georgia, USA & $\begin{array}{l}\text { African American } \\
\text { primary caregivers } \\
\text { of 11-year-old } \\
\text { children }\end{array}$ & $\begin{array}{l}\text { To examine the implementation and fidelity of } \\
\text { racial socialization activity within the Strong } \\
\text { African American Families program }\end{array}$ \\
\hline $\begin{array}{l}\text { Blitz et al., } \\
2016\end{array}$ & $\begin{array}{l}\text { Trauma and toxic } \\
\text { stress (TTS) }\end{array}$ & $\begin{array}{l}\text { Youth \& } \\
\text { adults }\end{array}$ & $\begin{array}{l}\text { Urban/ } \\
\text { Northeastern, USA }\end{array}$ & $\begin{array}{l}\text { Teachers, } \\
\text { classroom aides }\end{array}$ & $\begin{array}{l}\text { To investigate 1) perceptions of students' } \\
\text { behaviors, 2) understanding of TTS and race, and } \\
\text { 3) self-reported stress levels and teaching efficacy }\end{array}$ \\
\hline $\begin{array}{l}\text { Campbell et } \\
\text { al., } 2015\end{array}$ & Substance abuse & Adults & $\begin{array}{l}\text { Urban/Northern } \\
\text { Plains \& Pacific } \\
\text { Northwest, USA }\end{array}$ & $\begin{array}{l}\text { American } \\
\text { Indian/Alaskan } \\
\text { Native (AI/AN) } \\
\text { adults }\end{array}$ & $\begin{array}{l}\text { To assess the acceptability of a web-based version } \\
\text { of the community reinforcement approach } \\
\text { developed for substance abuse treatment seekers } \\
\text { at two outpatient programs }\end{array}$ \\
\hline \multirow[t]{2}{*}{$\begin{array}{l}\text { Carvajal et } \\
\text { al., } 2013\end{array}$} & $\begin{array}{l}\text { Study } 1 \text { : Border } \\
\text { community and } \\
\text { immigration stress \& } \\
\text { barriers to health care }\end{array}$ & Adults & $\begin{array}{l}\text { USA border } \\
\text { region/Arizona, USA }\end{array}$ & $\begin{array}{l}\text { Study 1: Latinos } \\
\text { (general } \\
\text { population); }\end{array}$ & $\begin{array}{l}\text { Study 1: To pilot a stress survey of mental health } \\
\text { indicators, physical health indicators, and } \\
\text { immigration-enforcement related mistreatment }\end{array}$ \\
\hline & $\begin{array}{l}\text { Study 2: Border } \\
\text { community } \\
\text { farmworker health } \\
\text { (stress) }\end{array}$ & & & $\begin{array}{l}\text { Study 2: Rural } \\
\text { farmworkers }\end{array}$ & $\begin{array}{l}\text { Study 2: To examine stress in order to promote } \\
\text { farmworker health in an agricultural community }\end{array}$ \\
\hline
\end{tabular}




\begin{tabular}{|c|c|c|c|c|c|}
\hline Study & Topic & $\begin{array}{l}\text { Target } \\
\text { Population }\end{array}$ & Geography/Location & Study Participants & Study Purpose \\
\hline $\begin{array}{l}\text { Conway et } \\
\text { al., } 2017\end{array}$ & $\begin{array}{l}\text { Care coordination \& } \\
\text { wellness }\end{array}$ & Adults & $\begin{array}{l}\text { Rural frontier } \\
\text { community/Ely, } \\
\text { Minnesota, USA }\end{array}$ & $\begin{array}{l}\text { Community Care } \\
\text { Team } \\
\text { organizations, } \\
\text { adult patients who } \\
\text { participated in } \\
\text { care coordination }\end{array}$ & $\begin{array}{l}\text { To describe the development of a rural, } \\
\text { grassroots-driven care coordination (medical } \\
\text { home) project }\end{array}$ \\
\hline $\begin{array}{l}\text { Crooks et al., } \\
2018\end{array}$ & $\begin{array}{l}\text { Cultural adaptation } \\
\text { of a mental health } \\
\text { curriculum }\end{array}$ & Adults & Canada & $\begin{array}{l}\text { First Nations and } \\
\text { Metis Nations }\end{array}$ & $\begin{array}{l}\text { The purpose of this study was to undertake a } \\
\text { feasibility study of the Mental Health First Aid } \\
\text { First Nations course to assess the acceptability of } \\
\text { the intervention and cultural adaptation, and } \\
\text { preliminary participant outcomes. }\end{array}$ \\
\hline $\begin{array}{l}\text { Dickerson et } \\
\text { al., } 2014\end{array}$ & $\begin{array}{l}\text { Substance abuse } \\
\text { treatment }\end{array}$ & Adults & $\begin{array}{l}\text { Urban/Los Angeles, } \\
\text { California, USA }\end{array}$ & $\mathrm{AI} / \mathrm{AN}$ adults & $\begin{array}{l}\text { To refine and test the drum-assisted therapy } \\
\text { intervention to facilitate the necessary } \\
\text { refinements to the DARTNA treatment manual } \\
\text { (e.g., intervention) }\end{array}$ \\
\hline $\begin{array}{l}\text { Ferguson, } \\
2012\end{array}$ & $\begin{array}{l}\text { Mental health } \\
\text { treatment and } \\
\text { employment services } \\
\text { for homeless youth }\end{array}$ & Youth & $\begin{array}{l}\text { Urban/Los Angeles, } \\
\text { California, USA }\end{array}$ & Homeless youth & $\begin{array}{l}\text { To demonstrate the utility of combining social } \\
\text { enterprise interventions with mental health care } \\
\text { of homeless youth }\end{array}$ \\
\hline $\begin{array}{l}\text { Ford et al., } \\
2019\end{array}$ & $\begin{array}{l}\text { School-based } \\
\text { intervention serving } \\
\text { primarily ethnic } \\
\text { minority girls }\end{array}$ & Youth & Urban/USA & $\begin{array}{l}\text { Program } \\
\text { counselors, } \\
\text { program } \\
\text { participants, } \\
\text { school staff, and } \\
\text { parents }\end{array}$ & $\begin{array}{l}\text { To conduct a participatory, formative evaluation } \\
\text { of a community-developed intervention with a } \\
\text { large sample of ethnic minority girls across } \\
\text { multiple schools. A secondary goal was to use } \\
\text { findings to inform continued program } \\
\text { improvement and prepare for a rigorous } \\
\text { outcomes evaluation }\end{array}$ \\
\hline $\begin{array}{l}\text { Goodyear- } \\
\text { Smith et al., } \\
2016\end{array}$ & Mental health & Youth & Rural/New Zealand & $\begin{array}{l}\text { Enrolled and non- } \\
\text { school enrolled } \\
\text { youth with a focus } \\
\text { on the Maori }\end{array}$ & $\begin{array}{l}\text { To pilot the YouthCHAT program, assess its } \\
\text { utility and acceptability for enrolled/non-school } \\
\text { enrolled youth and health clinic staff, and build a } \\
\text { framework for subsequent roll-out. }\end{array}$ \\
\hline
\end{tabular}




\begin{tabular}{|c|c|c|c|c|c|}
\hline Study & Topic & $\begin{array}{l}\text { Target } \\
\text { Population }\end{array}$ & Geography/Location & Study Participants & Study Purpose \\
\hline $\begin{array}{l}\text { Hanssmann } \\
\text { et al., } 2008\end{array}$ & $\begin{array}{l}\text { Multicultural \& } \\
\text { transgender } \\
\text { competence }\end{array}$ & Adults & $\begin{array}{l}\text { Urban/Seattle, } \\
\text { Washington, USA }\end{array}$ & $\begin{array}{l}\text { Healthcare } \\
\text { providers }\end{array}$ & $\begin{array}{l}\text { To determine whether competency trainings were } \\
\text { effective in increasing the clinical and cultural } \\
\text { competence of health care providers in delivering } \\
\text { care to transgender clients or patients }\end{array}$ \\
\hline $\begin{array}{l}\text { Hoffmann et } \\
\text { al., } 2015\end{array}$ & $\begin{array}{l}\text { Exercise for people } \\
\text { with severe \& } \\
\text { persistent mental } \\
\text { illness (SPMI) }\end{array}$ & Adults & $\begin{array}{l}\text { Urban/Pittsburgh, } \\
\text { Pennsylvania, USA }\end{array}$ & $\begin{array}{l}\text { Adults with SPMI } \\
\& \text { history of } \\
\text { violence or } \\
\text { substance abuse }\end{array}$ & $\begin{array}{l}\text { To tailor an exercise program for people with } \\
\text { SPMI }\end{array}$ \\
\hline $\begin{array}{l}\text { Jee et al., } \\
2015\end{array}$ & $\begin{array}{l}\text { Mindfulness based } \\
\text { stress reduction } \\
\text { program for } \\
\text { traumatized youth in } \\
\text { foster care }\end{array}$ & Youth & $\begin{array}{l}\text { Urban/New York, } \\
\text { USA }\end{array}$ & Youth, ages 14-21 & $\begin{array}{l}\text { 1) To measure baseline stress among a group of } \\
\text { youth in foster; 2) to design and implement a pilot } \\
\text { program to target stress reduction by adapting an } \\
\text { evidence-based group therapy technique; } 3 \text { ) to } \\
\text { measure impact on stress using psychological and } \\
\text { physiological techniques }\end{array}$ \\
\hline $\begin{array}{l}\text { Livingston et } \\
\text { al., } 2014\end{array}$ & $\begin{array}{l}\text { Mental health \& } \\
\text { police interactions }\end{array}$ & Adults & $\begin{array}{l}\text { Urban/Vancouver, } \\
\text { Canada }\end{array}$ & $\begin{array}{l}\text { Adults with } \\
\text { mental illness who } \\
\text { have had police } \\
\text { contact }\end{array}$ & $\begin{array}{l}\text { To examine the perceptions and experiences of } \\
\text { people with mental illness in relation to their } \\
\text { interactions with police }\end{array}$ \\
\hline $\begin{array}{l}\text { Marlow et } \\
\text { al., } 2015\end{array}$ & $\begin{array}{l}\text { Formerly } \\
\text { incarcerated adults } \\
\text { (self-esteem, self- } \\
\text { efficacy, social } \\
\text { support, coping, 12- } \\
\text { step participation) }\end{array}$ & Adults & $\begin{array}{l}\text { Urban/Alameda } \\
\text { County, California, } \\
\text { USA }\end{array}$ & Male parolees & $\begin{array}{l}\text { To assess the feasibility and impact of a peer } \\
\text { mentoring intervention for recently released men }\end{array}$ \\
\hline $\begin{array}{l}\text { Michalak et } \\
\text { al., } 2015\end{array}$ & $\begin{array}{l}\text { Stigma related to } \\
\text { bipolar disorder }\end{array}$ & Adults & Urban/Canada & $\begin{array}{l}\text { Adults } \\
\text { experiencing } \\
\text { bipolar disorder, } \\
\text { health care } \\
\text { providers }\end{array}$ & $\begin{array}{l}\text { To identify self-management strategies for bipolar } \\
\text { disorder for maintaining balance in mood and } \\
\text { stopping progression into hypomania. }\end{array}$ \\
\hline
\end{tabular}




\begin{tabular}{|c|c|c|c|c|c|}
\hline Study & Topic & $\begin{array}{l}\text { Target } \\
\text { Population }\end{array}$ & Geography/Location & Study Participants & Study Purpose \\
\hline $\begin{array}{l}\text { Michalak et } \\
\text { al., } 2019\end{array}$ & $\begin{array}{l}\text { Bipolar Disorder } \\
\text { Management }\end{array}$ & Adults & Urban/Canada & $\begin{array}{l}\text { Adults } \\
\text { experiencing } \\
\text { bipolar disorder }\end{array}$ & $\begin{array}{l}\text { To advance understanding of knowledge } \\
\text { translation strategies in bipolar disorder }\end{array}$ \\
\hline $\begin{array}{l}\text { Murray et al., } \\
2013\end{array}$ & $\begin{array}{l}\text { Trauma Focused- } \\
\text { Cognitive Behavioral } \\
\text { Therapy (TF-CBT) } \\
\text { adaptation and } \\
\text { process explanation }\end{array}$ & Youth & $\begin{array}{l}\text { Urban and low- } \\
\text { income/Lusaka, } \\
\text { Zambia }\end{array}$ & $\begin{array}{l}\text { Children and } \\
\text { adolescents who } \\
\text { experienced } \\
\text { trauma }\end{array}$ & $\begin{array}{l}\text { 1) To select an evidence-based trauma treatment } \\
\text { for children and adolescents, and 2) to describe } \\
\text { the adaptation of TF-CBT }\end{array}$ \\
\hline $\begin{array}{l}\text { Pakhale et } \\
\text { al., } 2018\end{array}$ & $\begin{array}{l}\text { Tobacco and } \\
\text { Substance use }\end{array}$ & $\begin{array}{l}\text { Youth \& } \\
\text { adults }\end{array}$ & Urban, Canada & $\begin{array}{l}\text { Individuals } 16+ \\
\text { using drugs and } \\
\text { tobacco }\end{array}$ & $\begin{array}{l}\text { To assess the feasibility of implementing a } \\
\text { community-based participatory tobacco } \\
\text { dependence strategy in Ottawa's inner city }\end{array}$ \\
\hline $\begin{array}{l}\text { Russell et al., } \\
2019\end{array}$ & $\begin{array}{l}\text { Illicit drug use in } \\
\text { youth }\end{array}$ & $\begin{array}{l}\text { Youth \& } \\
\text { adult }\end{array}$ & Rural/Canada & $\begin{array}{l}\text { Youth and key } \\
\text { informants }\end{array}$ & $\begin{array}{l}\text { To pilot test both prevention interventions and } \\
\text { assess barriers to and facilitators of intervention } \\
\text { implementation }\end{array}$ \\
\hline $\begin{array}{l}\text { Sampson et } \\
\text { al., } 2013\end{array}$ & Stress \& asthma & $\begin{array}{l}\text { Youth \& } \\
\text { adults }\end{array}$ & $\begin{array}{l}\text { Low income } \\
\text { neighborhoods/ } \\
\text { Detroit \& Dearborn, } \\
\text { Michigan, USA }\end{array}$ & $\begin{array}{l}\text { Caregivers of } \\
\text { children with } \\
\text { asthma }\end{array}$ & $\begin{array}{l}\text { To communicate how low-income caregivers } \\
\text { conceptualize stress }\end{array}$ \\
\hline $\begin{array}{l}\text { Shannon et } \\
\text { al., } 2016\end{array}$ & $\begin{array}{l}\text { Mental health } \\
\text { service referral } \\
\text { process for refugees }\end{array}$ & $\begin{array}{l}\text { Youth \& } \\
\text { adults }\end{array}$ & $\begin{array}{l}\text { Urban/Minnesota, } \\
\text { USA }\end{array}$ & $\begin{array}{l}\text { Mental health } \\
\text { providers }\end{array}$ & $\begin{array}{l}\text { To examine providers' perspectives on key } \\
\text { characteristics of successful and unsuccessful } \\
\text { referral processes for refugees in need of mental } \\
\text { health services }\end{array}$ \\
\hline $\begin{array}{l}\text { Staudt et al., } \\
2015\end{array}$ & $\begin{array}{l}\text { Latino health } \\
\text { disparities in } \\
\text { "colonia" }\end{array}$ & $\begin{array}{l}\text { Youth \& } \\
\text { adults }\end{array}$ & $\begin{array}{l}\text { Colonia/El Paso, } \\
\text { Texas, USA }\end{array}$ & $\begin{array}{l}\text { Households in } \\
\text { Colonia }\end{array}$ & $\begin{array}{l}\text { To examines the incidence of cancer, respiratory } \\
\text { health, and mental illness among Hispanics living } \\
\text { in Westway colonia (adjacent to a steel recycling } \\
\text { plant) }\end{array}$ \\
\hline
\end{tabular}




\begin{tabular}{|c|c|c|c|c|c|}
\hline Study & Topic & $\begin{array}{l}\text { Target } \\
\text { Population }\end{array}$ & Geography/Location & Study Participants & Study Purpose \\
\hline $\begin{array}{l}\text { Suchman et } \\
\text { al., } 2020\end{array}$ & Parenting & Adults & Urban/South Africa & $\begin{array}{l}\text { High risk mothers } \\
\text { and treatment } \\
\text { providers }\end{array}$ & $\begin{array}{l}\text { To examine the feasibility and acceptability of } \\
\text { adapting an evidence-based parenting } \\
\text { intervention called Mothering from the Inside Out }\end{array}$ \\
\hline $\begin{array}{l}\text { Vaughn et } \\
\text { al., } 2013\end{array}$ & Obesity \& bullying & $\begin{array}{l}\text { Youth \& } \\
\text { adults }\end{array}$ & $\begin{array}{l}\text { Urban/Cincinnati, } \\
\text { Ohio, USA }\end{array}$ & $\begin{array}{l}\text { K-8 students, } \\
\text { parents, college } \\
\text { students, school } \\
\text { staff, and } \\
\text { administrators }\end{array}$ & $\begin{array}{l}\text { To allow stakeholders, including students, to } \\
\text { generate and prioritize specific strategies to } \\
\text { address obesity and bullying }\end{array}$ \\
\hline $\begin{array}{l}\text { Vaughn et } \\
\text { al., } 2016\end{array}$ & $\begin{array}{l}\text { Obesity, stress, } \\
\text { coping }\end{array}$ & Adults & $\begin{array}{l}\text { Urban \& rural/ } \\
\text { Hamilton County, } \\
\text { Ohio, USA }\end{array}$ & $\begin{array}{l}\text { Latino immigrant } \\
\text { community } \\
\text { members and } \\
\text { Latino-serving } \\
\text { providers }\end{array}$ & $\begin{array}{l}\text { To (1) generate strategies to address obesity, } \\
\text { stress and coping, and healthcare navigation that } \\
\text { are contextually appropriate and applicable; (2) } \\
\text { identify the most salient strategies within the } \\
\text { areas of obesity, stress and coping, and healthcare } \\
\text { navigation; and (3) use the results to develop } \\
\text { specific interventions to improve Latino health in } \\
\text { the local region }\end{array}$ \\
\hline $\begin{array}{l}\text { Woods- } \\
\text { Jaeger et al., } \\
2018\end{array}$ & Toxic stress & $\begin{array}{l}\text { Youth \& } \\
\text { adults }\end{array}$ & Urban/USA & $\begin{array}{l}\text { Parents and their } \\
\text { children, teachers, } \\
\text { and therapists }\end{array}$ & $\begin{array}{l}\text { To implement two interventions in a community- } \\
\text { based, early education setting that promote } \\
\text { positive, nurturing parent-child and teacher-child } \\
\text { relationships }\end{array}$ \\
\hline
\end{tabular}


Jones et al., 2020

\section{MMR Characteristics}

MMR designs should be driven by the intent of the study and include a rationale for the selected design based on how the quantitative and qualitative methods are integrated (Fetters et al., 2013). As listed in Table 1, several MMR designs have been established (Creswell \& Plano Clark, 2018). An explicit MMR rationale was stated in $35 \%(n=10)$ of the articles and MMR methodological references were cited in $28 \%(n=8)$ (see Table 3). In our review, $31 \%(n=9)$ of the studies used a convergent design, where data collection and analysis for both methods were conducted at approximately the same time and then merged during analysis for comparison. Another $31 \%(\mathrm{n}=9)$ of the studies used explanatory sequential designs in which the qualitative approach follows the quantitative approach in order to explain the quantitative results. In an exploratory sequential design $(14 \%, n=4)$, the qualitative approach precedes the quantitative approach. In 6 of the 29 articles (21\%), an intramethod design was used which involves the use of both quantitative and qualitative methods using the same dataset or data collection technique. Finally, one study used a multiphase design that incorporated more than two phases of quantitative and qualitative data collection.

Self-report questionnaires such as surveys and pre/post assessments were predominantly featured among the studies, with $90 \%(n=26)$ of the studies using these data collection methods. Of these, $21 \%(n=6)$ included openended questions. Seven percent $(n=2)$ of the studies incorporated administrative data related to the program participants. The qualitative data collection methods represented in the studies were more varied. Fourteen studies (48\%) used interviews and 28\% $(n=8)$ used focus groups. A variety of other qualitative data collection methods were utilized, $(31 \%, n=9)$, such as video analysis, module feedback, patient document review, observations, narratives, process notes, meeting notes, observations, and written notes. Concept mapping, which has been defined as an intramethod data collection method, was represented in two studies (7\%).

A core feature of mixed methods research is integration: the intentional mixing or combining of the quantitative and qualitative data sets (Fetters et al., 2013). In the implementation of a mixed methods design, researchers choose among three main procedures based on the intent of integration in the study: (1) connecting, or using one data set to explain the findings in the other data set; (2) building, or using one data set to build or develop the data collection strategy for the next data collection phase; (3) merging, or comparing the results of the quantitative phase with the results of the qualitative phase; and (4) embedding, or mixing qualitative and quantitative data sets at multiple points in the research design using any combination of connecting, building, and merging. Of the reviewed studies, $66 \%(n=19)$ evidenced connecting as their integration strategy during implementation. For example, Hanssmann et al. (2008) used connecting to integrate pre- and post-questionnaires data with follow-up interviews in an effort to evaluate training and develop competency recommendations for healthcare providers working with transgender and gender-nonconforming clients. Eight of the training participants were interviewed to gain a deeper understanding of what was learned from the questionnaire results. From the qualitative data, the researchers were able to identify knowledge retained by the participants and potential gaps in the training delivered. Following connecting, merging was used in $45 \%$ of studies $(n=13)$, while building and embedding were used the least, $10 \%(n=3)$ and $<1 \%(n=2)$, respectively. Around $31 \%(n=9)$ of the studies evidenced more than one integration method.

When reporting their findings and discussion, authors used at least one of three primary integration strategies: narrative (describing the findings of both data sets together), data transformation (turning qualitative data into quantitative data for quantitative analysis, or vice versa), or joint displays (visual matrices or figures that show quantitative and qualitative results together). The vast majority of studies (86\%, $\mathrm{n}=25$ ) used narrative strategies to describe their mixed methods results, similar to what would be done when reporting the results of individual quantitative or qualitative studies. This large percentage was followed by joint displays $(10 \%, \mathrm{n}=3)$ and data transformation $(<1 \%, \mathrm{n}=2)$. Two studies $(<1 \%)$ used more than one integration interpretation approach. 
Table 3: MMR Features of Included Studies

\begin{tabular}{|c|c|c|c|c|c|c|c|}
\hline Study & $\begin{array}{l}\text { MMR } \\
\text { Design }\end{array}$ & MMR Methods \& Sample Size & MMR Rationale & $\begin{array}{l}\text { MMR } \\
\text { Language }\end{array}$ & $\begin{array}{l}\text { MMR } \\
\text { References }\end{array}$ & $\begin{array}{l}\text { Integration } \\
\text { Methods }\end{array}$ & $\begin{array}{l}\text { Integration } \\
\text { Interpretation }\end{array}$ \\
\hline $\begin{array}{l}\text { Barnett et al., } \\
2018\end{array}$ & Convergent & $\begin{array}{l}\text { Survey }(\mathrm{n}=10) \\
\text { Interviews }(\mathrm{n}=9)\end{array}$ & No & No & No & $\begin{array}{l}\text { Connecting } \\
\text { Merging }\end{array}$ & Narrative \\
\hline $\begin{array}{l}\text { Bell et al., } \\
2014\end{array}$ & $\begin{array}{l}\text { Exploratory } \\
\text { sequential }\end{array}$ & $\begin{array}{l}\text { Survey }(n=80) \\
\text { BMI measurement }(n=80) \\
\text { Interviews }(n=16) \\
\text { Focus groups }(n=31)\end{array}$ & $\begin{array}{l}\text { Tailor the intervention } \\
\text { and survey for the } \\
\text { target audience }\end{array}$ & No & No & Merging & Narrative \\
\hline $\begin{array}{l}\text { Berkel et al., } \\
2013\end{array}$ & Convergent & $\begin{array}{l}\text { Fidelity measure/video } \\
\text { analysis }(n=20 \text { groups }) \\
\text { Questionnaires }(n=332)\end{array}$ & No & No & No & $\begin{array}{l}\text { Connecting } \\
\text { Merging }\end{array}$ & Narrative \\
\hline $\begin{array}{l}\text { Blitz et al., } \\
2016\end{array}$ & Convergent & $\begin{array}{l}\text { Questionnaires }(n=42) \\
\text { Interviews }(n=29)\end{array}$ & No & No & No & Connecting & Narrative \\
\hline $\begin{array}{l}\text { Campbell et } \\
\text { al., } 2015\end{array}$ & $\begin{array}{l}\text { Explanatory } \\
\text { sequential }\end{array}$ & $\begin{array}{l}\text { Baseline substance use } \\
(\mathrm{n}=40) \\
\text { Module feedback survey } \\
(\mathrm{n}=40) \\
\text { Follow-up assessment with } \\
\text { closed/open-ended questions } \\
(\mathrm{n}=26) \\
\text { Interviews }(\mathrm{n}=26)\end{array}$ & No & Yes & No & $\begin{array}{l}\text { Connecting } \\
\text { Merging }\end{array}$ & Narrative \\
\hline $\begin{array}{l}\text { Carvajal et } \\
\text { al., } 2013\end{array}$ & Intramethod & $\begin{array}{l}\text { Study 1: Survey with } \\
\text { closed/open-ended questions } \\
(\mathrm{n}=147) \\
\text { Study 2: Survey with } \\
\text { closed/open-ended questions } \\
(\mathrm{n}=299)\end{array}$ & No & Yes & No & Connecting & Narrative \\
\hline
\end{tabular}




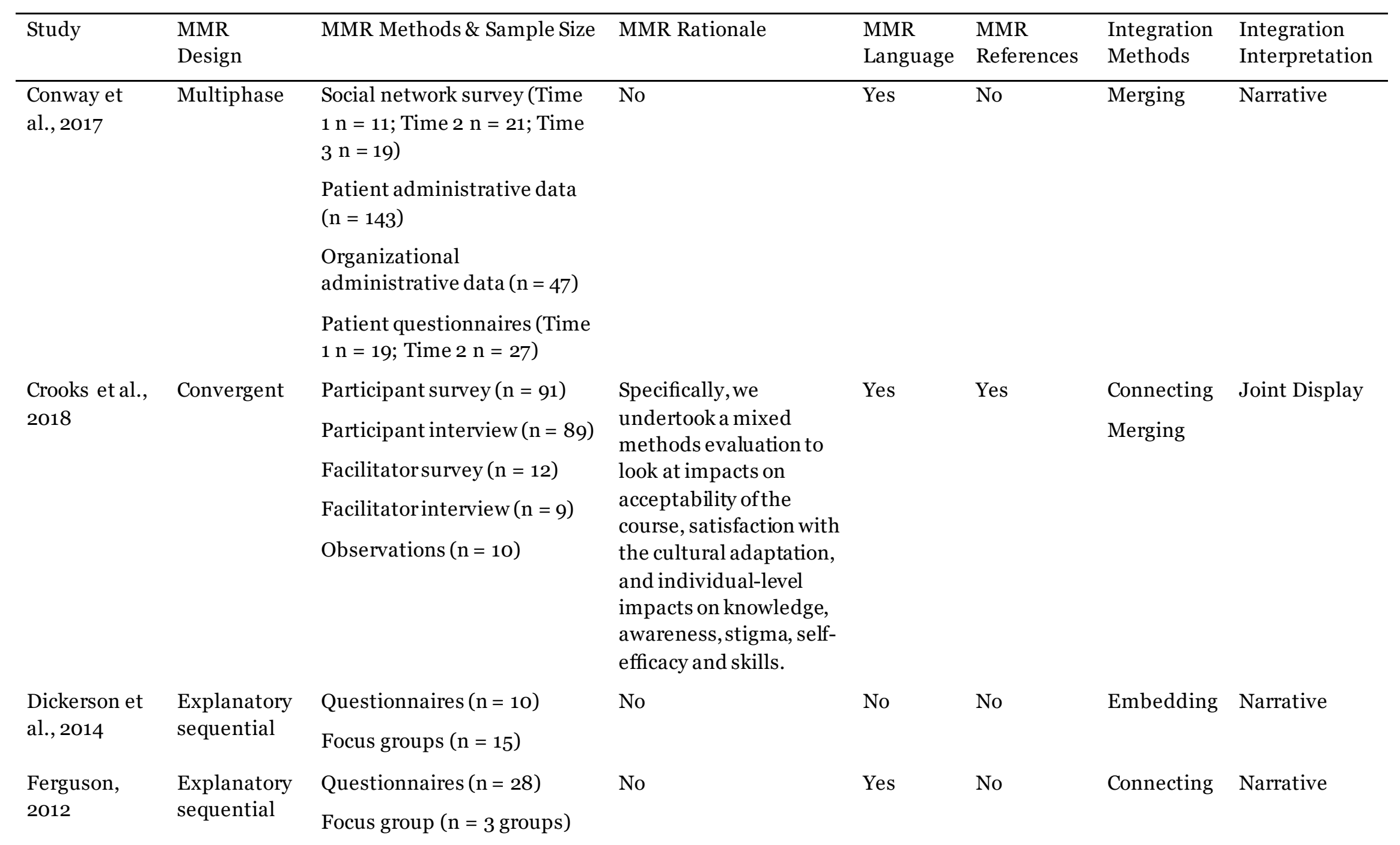




\begin{tabular}{|c|c|c|c|c|c|c|c|}
\hline Study & $\begin{array}{l}\text { MMR } \\
\text { Design }\end{array}$ & MMR Methods \& Sample Size & MMR Rationale & $\begin{array}{l}\text { MMR } \\
\text { Language }\end{array}$ & $\begin{array}{l}\text { MMR } \\
\text { References }\end{array}$ & $\begin{array}{l}\text { Integration } \\
\text { Methods }\end{array}$ & $\begin{array}{l}\text { Integration } \\
\text { Interpretation }\end{array}$ \\
\hline $\begin{array}{l}\text { Ford-Paz et } \\
\text { al., } 2019\end{array}$ & $\begin{array}{l}\text { Explanatory } \\
\text { Sequential }\end{array}$ & $\begin{array}{l}\text { Pre/Post Counselor Focus } \\
\text { Groups }(\mathrm{n}=17,18) \\
\text { Pre/Post teacher student } \\
\text { evaluation }(\mathrm{n}=660,661) \\
\text { Counselor Surveys }(\mathrm{n}=18) \\
\text { End-of-year survey }(\mathrm{n}=585) \\
\text { Standardized measures } \\
\text { Administrative data }\end{array}$ & $\begin{array}{l}\text { Applied, mixed methods } \\
\text { research lendsitself well } \\
\text { to community } \\
\text { collaboration and } \\
\text { enhances the credibility } \\
\text { and relevance of study } \\
\text { outcomes byseeking } \\
\text { comprehensive answers } \\
\text { to research questions } \\
\text { and integrating multi- } \\
\text { informant quantitative } \\
\text { and qualitative data to } \\
\text { reach justifiable } \\
\text { conclusions. }\end{array}$ & Yes & Yes & $\begin{array}{l}\text { Connecting } \\
\text { Merging }\end{array}$ & Narrative \\
\hline $\begin{array}{l}\text { Goodyear- } \\
\text { Smith et al., } \\
2016\end{array}$ & Convergent & $\begin{array}{l}\text { YouthCHAT Domains } \\
(\mathrm{n}=30) \\
\text { Questionnaires }(\mathrm{n}=30) \\
\text { Surveys }(\mathrm{n}=30) \\
\text { Focus group }(\mathrm{n}=5) \\
\text { Interviews }(\mathrm{n}=2)\end{array}$ & No & No & No & Merging & Narrative \\
\hline $\begin{array}{l}\text { Hanssmann } \\
\text { et al., } 2008\end{array}$ & $\begin{array}{l}\text { Explanatory } \\
\text { sequential }\end{array}$ & $\begin{array}{l}\text { Questionnaires }(\mathrm{n}=55) \\
\text { Interviews }(\mathrm{n}=9)\end{array}$ & No & Yes & No & Connecting & Narrative \\
\hline $\begin{array}{l}\text { Hoffmann et } \\
\text { al., } 2015\end{array}$ & $\begin{array}{l}\text { Exploratory } \\
\text { sequential }\end{array}$ & $\begin{array}{l}\text { Survey }(\mathrm{n}=16) \\
\text { Focus group }(\mathrm{n}=14) \\
\text { Open-ended questionnaire } \\
(\mathrm{n}=16) \\
\text { Document review }\end{array}$ & No & No & No & Building & $\begin{array}{l}\text { Narrative } \\
\text { Joint display }\end{array}$ \\
\hline
\end{tabular}




\begin{tabular}{|c|c|c|c|c|c|c|c|}
\hline Study & $\begin{array}{l}\text { MMR } \\
\text { Design }\end{array}$ & MMR Methods \& Sample Size & MMR Rationale & $\begin{array}{l}\text { MMR } \\
\text { Language }\end{array}$ & $\begin{array}{l}\text { MMR } \\
\text { References }\end{array}$ & $\begin{array}{l}\text { Integration } \\
\text { Methods }\end{array}$ & $\begin{array}{l}\text { Integration } \\
\text { Interpretation }\end{array}$ \\
\hline $\begin{array}{l}\text { Jee et al., } \\
2015\end{array}$ & $\begin{array}{l}\text { Explanatory } \\
\text { sequential }\end{array}$ & $\begin{array}{l}\text { Pre/Post youth measures } \\
(\mathrm{n}=42) \\
\text { Focus groups }(\mathrm{n}=22)\end{array}$ & $\begin{array}{l}\text { In an effort to augment } \\
\text { our quantitative data } \\
\text { analysis we also } \\
\text { collected qualitative } \\
\text { data. }\end{array}$ & No & No & Connecting & Narrative \\
\hline $\begin{array}{l}\text { Livingston et } \\
\text { al., } 2014\end{array}$ & Intramethod & $\begin{array}{l}\text { Survey with closed/open- } \\
\text { ended questions }(n=60)\end{array}$ & No & Yes & No & Connecting & Narrative \\
\hline $\begin{array}{l}\text { Marlow et al., } \\
2015\end{array}$ & $\begin{array}{l}\text { Explanatory } \\
\text { sequential }\end{array}$ & $\begin{array}{l}\text { Questionnaires }(\mathrm{n}=20) \\
\text { Interviews }(\mathrm{n}=13)\end{array}$ & No & Yes & No & $\begin{array}{l}\text { Connecting } \\
\text { Merging }\end{array}$ & Narrative \\
\hline $\begin{array}{l}\text { Michalak et } \\
\text { al., } 2015\end{array}$ & $\begin{array}{l}\text { Explanatory } \\
\text { sequential }\end{array}$ & $\begin{array}{l}\text { Questionnaires }(\mathrm{n}=164) \\
\text { Interviews }(\mathrm{n}=33)\end{array}$ & $\begin{array}{l}\text { Findings from the } \\
\text { quantitative analysis } \\
\text { were used to develop the } \\
\text { qualitative interviews } \\
\text { Quantitative findings } \\
\text { used for purposeful } \\
\text { sampling of participants } \\
\text { in follow-up interviews }\end{array}$ & Yes & Yes & Connecting & $\begin{array}{l}\text { Narrative } \\
\text { Joint display }\end{array}$ \\
\hline $\begin{array}{l}\text { Michalak et } \\
\text { al., } 2019\end{array}$ & $\begin{array}{l}\text { Explanatory } \\
\text { sequential }\end{array}$ & $\begin{array}{l}\text { Questionnaires }(\mathrm{n}=94) \\
\text { Interviews }(\mathrm{n}=43)\end{array}$ & No & Yes & Yes & Connecting & Narrative \\
\hline $\begin{array}{l}\text { Murray et al., } \\
2013\end{array}$ & $\begin{array}{l}\text { Exploratory } \\
\text { sequential }\end{array}$ & $\begin{array}{l}\text { Questionnaires }(\mathrm{n}=21) \\
\text { Interviews }(\mathrm{n}=66) \\
\text { Written notes }\end{array}$ & $\begin{array}{l}\text { Develop a cultural } \\
\text { adaptation of the } \\
\text { intervention }\end{array}$ & No & No & Building & Narrative \\
\hline $\begin{array}{l}\text { Pakhale et } \\
\text { al., } 2018\end{array}$ & Convergent & $\begin{array}{l}\text { Questionnaires with open } \\
\text { ended questions }(\mathrm{n}=80)\end{array}$ & No & Yes & No & Merging & Narrative \\
\hline $\begin{array}{l}\text { Russell et al., } \\
2019\end{array}$ & Convergent & $\begin{array}{l}\text { Questionnaires }(\mathrm{n}=100) \\
\text { Focus groups/Interviews } \\
(\mathrm{n}=137)\end{array}$ & No & Yes & Yes & Connecting & Narrative \\
\hline
\end{tabular}




\begin{tabular}{|c|c|c|c|c|c|c|c|}
\hline Study & $\begin{array}{l}\text { MMR } \\
\text { Design }\end{array}$ & MMR Methods \& Sample Size & MMR Rationale & $\begin{array}{l}\text { MMR } \\
\text { Language }\end{array}$ & $\begin{array}{l}\text { MMR } \\
\text { References }\end{array}$ & $\begin{array}{l}\text { Integration } \\
\text { Methods }\end{array}$ & $\begin{array}{l}\text { Integration } \\
\text { Interpretation }\end{array}$ \\
\hline $\begin{array}{l}\text { Sampson et } \\
\text { al., } 2013\end{array}$ & Convergent & $\begin{array}{l}\text { Survey }(n=40) \\
\text { Interviews }(n=40)\end{array}$ & No & No & No & Connecting & Narrative \\
\hline $\begin{array}{l}\text { Shannon et } \\
\text { al., } 2016\end{array}$ & Intramethod & $\begin{array}{l}\text { Survey }(n=64) \\
\text { Narratives }(n=64)\end{array}$ & $\begin{array}{l}\text { Obtain rich description } \\
\text { and factors related to } \\
\text { successful referrals }\end{array}$ & Yes & Yes & $\begin{array}{l}\text { Connecting } \\
\text { Merging }\end{array}$ & Narrative \\
\hline $\begin{array}{l}\text { Suchman et } \\
\text { al., } 2020\end{array}$ & $\begin{array}{l}\text { Exploratory } \\
\text { sequential }\end{array}$ & $\begin{array}{l}\text { Questionnaires }(\mathrm{n}=25) \\
\text { Process notes } \\
\text { Meeting notes }\end{array}$ & No & Yes & No & Building & Narrative \\
\hline $\begin{array}{l}\text { Woods- } \\
\text { Jaeger et al., } \\
2018\end{array}$ & Convergent & $\begin{array}{l}\text { Youth questionnaires } \\
(\mathrm{n}=86) \\
\text { Parent questionnaires }(\mathrm{n}=8) \\
\text { Interviews }(\mathrm{n}=26) \\
\text { Observations }(\mathrm{n}=2) \\
\text { Clinical notes }\end{array}$ & $\begin{array}{l}\text { Using multiple methods } \\
\text { allows for a more } \\
\text { comprehensive } \\
\text { understanding of } \\
\text { feasibilityin the target } \\
\text { population and also } \\
\text { makes it possibleto } \\
\text { identify modifications } \\
\text { and refinements. }\end{array}$ & Yes & Yes & $\begin{array}{l}\text { Merging } \\
\text { Embedding } \\
\text { (qual } \\
\text { priority) }\end{array}$ & Connecting \\
\hline
\end{tabular}


Jones et al., 2020

\section{CBPR Characteristics}

The articles included in this review were analyzed for the key features of CBPR represented in mental health studies. Although the studies explicitly referenced the use of a CBPR approach, details about implementation of the approach were often lacking. The results pre sented here are based on what we were able to discern from the available article descriptions, which may or may not fully depict the use of CBPR in those studies. Table 4 displays each of the articles alongside evidence of the key features that were described.

Of the 29 articles, 18 (62\%) provided an explicit rationale for their use of CBPR in the study. The most frequently stated rationale for using CBPR was related to tailoring a program or intervention for the focal population so that it was more relevant and culturally appropriate. Ten out of the 18 studies provided a rationale. For example, Hoffman et al. (2015) stated their rationale was to "increase our ability to tailor the intervention to the needs of the community and ensure the community's needs are addressed"(p. 214). Other studies $(21 \%, \mathrm{n}=6)$ described using a CBPR approach to address community concerns and incorporate community perspectives on the study issue and findings. Additional rationales, which were each represented by two studies, included using research to promote community action, enhancing research quality, and establishing positive community-academic relationships.

Typically, CBPR approaches include academic researchers partnering with a variety of community memb ers, including laypeople as well as professional stakeholders. In the current review of MMCBPR studies for mental health, we found that most of the studies $(59 \%, \mathrm{n}=17)$ partnered directly with community members, such as community residents, tribal members, and members of the focal population. For instance, Bell et al. (2014) partnered with Lumbee Tribe of North Carolina in a study of bullying among American Indians. The next most reported type of partners was staff of community-based organizations, including treatment providers (n $=13 ; 45 \%)$. Lastly, four (14\%) studies partnered with "other" types of stakeholders, which included school personnel, a community advisory board, and faith-based leaders. Nine of the 20 studies (31\%) included more than one type of CBPR partner and only one (3\%) did not clearly identify who was involved in the CBPR partnership.

Each article was analyzed for evidence of the nine CBPR principles based on the partnership descriptions provided in the article. Evidence of at least one principle was found in every article and all nine principles were represented in two articles (see Bell et al., 2014 and Conway et al., 2017), while three articles indicated alignment with only one principle. The most common principle for which there was evidence was Collaborative Partnership Across all Phases of Research ( $\mathrm{n}=26$; 90\%). This was followed by Co-Learning and Capacity Building $(69 \%, \mathrm{n}=20)$, Strengths-based Orientation Towards Community $(65 \%, \mathrm{n}=19)$, and Phenomenon Under Investigation is Relevant to Community $(59 \%, \mathrm{n}=17)$ The least indicated principles were: Community Members Define Community $(n=9)$, Research Process is Cyclical and Iterative ( $n=10)$, and Long-term Commitment $(\mathrm{n}=10)$.

This review focused on the intersection of MMR and CBPR within mental health studies to inform psychological research. Therefore, we examined where the CBPR partnership used MMR in the research cycle. Most studies employed MMR approaches during the Designing and Conducting Research phase of CBPR $(90 \%, n=26)$. Half of the studies in this phase $(52 \%, n=15)$ employed MMR for the purpose of intervention development. For example, Marlow and colleagues (2015) described MMR within their CBPR partnership to pilot and evaluate a peer mentoring program for male parolees. Other studies used MMR in the Designing and Conducting Research phase for the purpose of data collection $(21 \%, \mathrm{n}=6)$, intervention implementation $(17 \%$, $\mathrm{n}=5$ ), and instrument development $(14 \%, \mathrm{n}=4)$. Five of the 29 studies employed MMR for two purposes in the same study (e.g., intervention development and intervention implementation). Of the remaining three studies that used MMR outside of the Designing and Conducting Research phase, two used an MMR approach to Identify Priority Issues and the other for Assessing Community Strengths and Dynamics. 
Table 4: CBPR Features of Included Studies

\begin{tabular}{|c|c|c|c|c|}
\hline Study & CBPR Rationale & CBPR Partners & CBPR Principles & Phase of MMR in CBPR Cycle \\
\hline $\begin{array}{l}\text { Barnett et al., } \\
2018\end{array}$ & $\begin{array}{l}\text { To develop a field guide that is } \\
\text { "relevant, useful, feasible, and } \\
\text { acceptable to all stakeholders" }\end{array}$ & $\begin{array}{l}\text { Former foster youth, foster } \\
\text { parents, birth parents, clinical } \\
\text { staff, administrators, } \\
\text { academic researchers }\end{array}$ & $\begin{array}{l}\text { Strengths based } \\
\text { Collaborative partnership } \\
\text { Co-Learning/capacity building } \\
\text { Action oriented } \\
\text { Relevant to community } \\
\text { Dissemination }\end{array}$ & $\begin{array}{l}\text { Designing \& conducting } \\
\text { research-Intervention } \\
\text { development }\end{array}$ \\
\hline $\begin{array}{l}\text { Bell et al., } \\
2014\end{array}$ & $\mathrm{~N} / \mathrm{A}$ & Tribe members & $\begin{array}{l}\text { Community defined } \\
\text { Strengths based } \\
\text { Collaborative partnership } \\
\text { Co-Learning/capacity building } \\
\text { Action oriented } \\
\text { Relevant to community } \\
\text { Cyclical process } \\
\text { Dissemination } \\
\text { Long-Term commitment }\end{array}$ & Identifying priority issues \\
\hline $\begin{array}{l}\text { Berkel et al., } \\
2013\end{array}$ & $\begin{array}{l}\text { Program adaptation to make } \\
\text { the intervention more relevant } \\
\text { to the target population }\end{array}$ & Community members & $\begin{array}{l}\text { Strengths based } \\
\text { Collaborative partnership } \\
\text { Co-Learning/capacity building } \\
\text { Long-Term commitment }\end{array}$ & $\begin{array}{l}\text { Designing \& conducting } \\
\text { research-Intervention } \\
\text { development }\end{array}$ \\
\hline $\begin{array}{l}\text { Blitz et al., } \\
2016\end{array}$ & $\begin{array}{l}\text { 1) Address complex } \\
\text { school/community concern; } \\
\text { 2) provide important insights } \\
\text { into school innovations }\end{array}$ & $\begin{array}{l}\text { School principal, teachers, } \\
\text { and other personnel }\end{array}$ & $\begin{array}{l}\text { Collaborative partnership } \\
\text { Relevant to community }\end{array}$ & $\begin{array}{l}\text { Designing \& conducting } \\
\text { research-data collection } \\
\text { (general), intervention } \\
\text { development }\end{array}$ \\
\hline
\end{tabular}




\begin{tabular}{|c|c|c|c|c|}
\hline $\begin{array}{l}\text { Campbell et } \\
\text { al., } 2015\end{array}$ & $\begin{array}{l}\text { 1) Ongoing community- } \\
\text { academic relationships that } \\
\text { promote bi-directional } \\
\text { communication, engagement, } \\
\text { and trust among stakeholders; } \\
\text { 2) increased efficiency and } \\
\text { quality of research efforts }\end{array}$ & Treatment program staff & $\begin{array}{l}\text { Collaborative partnership } \\
\text { Long-Term commitment }\end{array}$ & $\begin{array}{l}\text { Designing \& conducting } \\
\text { research-Intervention } \\
\text { development }\end{array}$ \\
\hline $\begin{array}{l}\text { Carvajal et al., } \\
2013\end{array}$ & $\mathrm{~N} / \mathrm{A}$ & Community members & $\begin{array}{l}\text { Community defined } \\
\text { Strengths based } \\
\text { Collaborative partnership } \\
\text { Relevant to community }\end{array}$ & $\begin{array}{l}\text { Designing \& conducting } \\
\text { research-Data collection } \\
\text { (general) }\end{array}$ \\
\hline $\begin{array}{l}\text { Conway et al., } \\
2017\end{array}$ & N/A & $\begin{array}{l}\text { Community members, } \\
\text { primary care physician, clinic } \\
\text { administrator, project } \\
\text { directors, care coordinators, } \\
\text { organization administrators, } \\
\text { and staff }\end{array}$ & $\begin{array}{l}\text { Community defined } \\
\text { Strengths based } \\
\text { Collaborative partnership } \\
\text { Co-Learning/capacity building } \\
\text { Action oriented } \\
\text { Relevant to community } \\
\text { Cyclical process } \\
\text { Dissemination } \\
\text { Long-Term commitment }\end{array}$ & $\begin{array}{l}\text { Designing \& conducting } \\
\text { research-Intervention } \\
\text { implementation }\end{array}$ \\
\hline $\begin{array}{l}\text { Crooks et al., } \\
2018\end{array}$ & $\begin{array}{l}\text { "We approached this work } \\
\text { from a perspectivism lens by } \\
\text { enlisting stakeholders as co- } \\
\text { producers of knowledge, and } \\
\text { explicitly addressing culture } \\
\text { and contexts" }\end{array}$ & $\begin{array}{l}\text { First Nations and Metis } \\
\text { Nations peoples, academic } \\
\text { researchers }\end{array}$ & $\begin{array}{l}\text { Strengths based } \\
\text { Collaborative Partnership } \\
\text { Co-Learning/capacity building } \\
\text { Relevant to community } \\
\text { Dissemination }\end{array}$ & $\begin{array}{l}\text { Design \& conducting - } \\
\text { intervention development and } \\
\text { intervention }\end{array}$ \\
\hline
\end{tabular}




\begin{tabular}{|c|c|c|c|c|}
\hline $\begin{array}{l}\text { Dickerson et } \\
\text { al., } 2014\end{array}$ & $\begin{array}{l}\text { 1) Increase the validity of the } \\
\text { research; 2) establish } \\
\text { community trust; 3) develop a } \\
\text { culturally appropriate } \\
\text { intervention }\end{array}$ & Community advisory board & $\begin{array}{l}\text { Strengths based } \\
\text { Collaborative partnership } \\
\text { Co-Learning/capacity building } \\
\text { Action oriented } \\
\text { Relevant to community }\end{array}$ & $\begin{array}{l}\text { Designing \& conducting } \\
\text { research-Intervention } \\
\text { development }\end{array}$ \\
\hline $\begin{array}{l}\text { Ferguson, } \\
2012\end{array}$ & $\mathrm{~N} / \mathrm{A}$ & $\begin{array}{l}\text { Community-based homeless } \\
\text { youth agency }\end{array}$ & Collaborative partnership & $\begin{array}{l}\text { Designing \& conducting } \\
\text { research-Intervention } \\
\text { development }\end{array}$ \\
\hline $\begin{array}{l}\text { Ford-Paz et } \\
\text { al., } 2019\end{array}$ & $\begin{array}{l}\text { To develop a program that } \\
\text { was relevant, culturally } \\
\text { appropriate-effective to } \\
\text { community }\end{array}$ & $\begin{array}{l}\text { Community members, } \\
\text { program leadership, academic } \\
\text { researchers }\end{array}$ & $\begin{array}{l}\text { Community defined } \\
\text { Strengths based } \\
\text { Collaborative partnership } \\
\text { Co-Learning/capacity building } \\
\text { Action Oriented } \\
\text { Relevant to community } \\
\text { Cyclical process } \\
\text { Dissemination }\end{array}$ & $\begin{array}{l}\text { Designing \& conducting } \\
\text { research-Intervention } \\
\text { development }\end{array}$ \\
\hline $\begin{array}{l}\text { Goodyear- } \\
\text { Smith et al., } \\
2016\end{array}$ & $\begin{array}{l}\text { To engage stakeholders in } \\
\text { "real life" translation of the } \\
\text { program }\end{array}$ & Health clinic staff & $\begin{array}{l}\text { Collaborative partnership } \\
\text { Co-Learning/capacity building } \\
\text { Action oriented } \\
\text { Cyclical process } \\
\text { Dissemination }\end{array}$ & $\begin{array}{l}\text { Designing \& conducting } \\
\text { research-Instrument } \\
\text { development }\end{array}$ \\
\hline $\begin{array}{l}\text { Hanssmann et } \\
\text { al., } 2008\end{array}$ & $\mathrm{~N} / \mathrm{A}$ & Non-profit clinic staff & $\begin{array}{l}\text { Community defined } \\
\text { Collaborative partnership } \\
\text { Co-Learning/capacity building } \\
\text { Action oriented } \\
\text { Dissemination }\end{array}$ & $\begin{array}{l}\text { Designing \& conducting } \\
\text { research-Intervention } \\
\text { implementation }\end{array}$ \\
\hline
\end{tabular}




\begin{tabular}{|c|c|c|c|c|}
\hline $\begin{array}{l}\text { Hoffmann et } \\
\text { al., } 2015\end{array}$ & $\begin{array}{l}\text { To address community needs } \\
\text { through a tailored } \\
\text { intervention }\end{array}$ & $\begin{array}{l}\text { Community members, } \\
\text { community-based } \\
\text { organization staff and interns }\end{array}$ & $\begin{array}{l}\text { Strengths based } \\
\text { Collaborative partnership } \\
\text { Co-Learning/capacity building } \\
\text { Action oriented } \\
\text { Relevant to community } \\
\text { Cyclical process } \\
\text { Dissemination }\end{array}$ & $\begin{array}{l}\text { Designing \& conducting } \\
\text { research-Intervention } \\
\text { development }\end{array}$ \\
\hline Jee et al., 2015 & $\begin{array}{l}\text { To have "youth-directed" } \\
\text { feedback to tailor training } \\
\text { curriculum. }\end{array}$ & Youth & $\begin{array}{l}\text { Collaborative partnership } \\
\text { Co-Learning/capacity building } \\
\text { Action oriented }\end{array}$ & $\begin{array}{l}\text { Designing \& conducting- } \\
\text { Intervention development and } \\
\text { randomized controlled trial }\end{array}$ \\
\hline $\begin{array}{l}\text { Livingston et } \\
\text { al., } 2014\end{array}$ & $\mathrm{~N} / \mathrm{A}$ & Community members & $\begin{array}{l}\text { Strengths based } \\
\text { Collaborative partnership } \\
\text { Co-Learning/capacity building } \\
\text { Relevant to community }\end{array}$ & $\begin{array}{l}\text { Designing \& conducting } \\
\text { research-Data collection }\end{array}$ \\
\hline $\begin{array}{l}\text { Marlow et al., } \\
2015\end{array}$ & $\begin{array}{l}\text { To include the target } \\
\text { population in the } \\
\text { development of services }\end{array}$ & $\begin{array}{l}\text { Community-based } \\
\text { organization staff }\end{array}$ & $\begin{array}{l}\text { Community defined } \\
\text { Strengths based } \\
\text { Collaborative partnership } \\
\text { Co-Learning/capacity building } \\
\text { Action oriented } \\
\text { Relevant to community } \\
\text { Long-Term commitment }\end{array}$ & $\begin{array}{l}\text { Designing \& conducting } \\
\text { research-Intervention } \\
\text { development }\end{array}$ \\
\hline $\begin{array}{l}\text { Michalak et } \\
\text { al., } 2015\end{array}$ & $\begin{array}{l}\text { 1) Ensure the research process } \\
\text { reflects community member } \\
\text { perspectives; 2) generate } \\
\text { knowledge that contributes to } \\
\text { social change }\end{array}$ & Community members & Collaborative partnership & $\begin{array}{l}\text { Designing \& conducting } \\
\text { research-Intervention } \\
\text { implementation }\end{array}$ \\
\hline
\end{tabular}




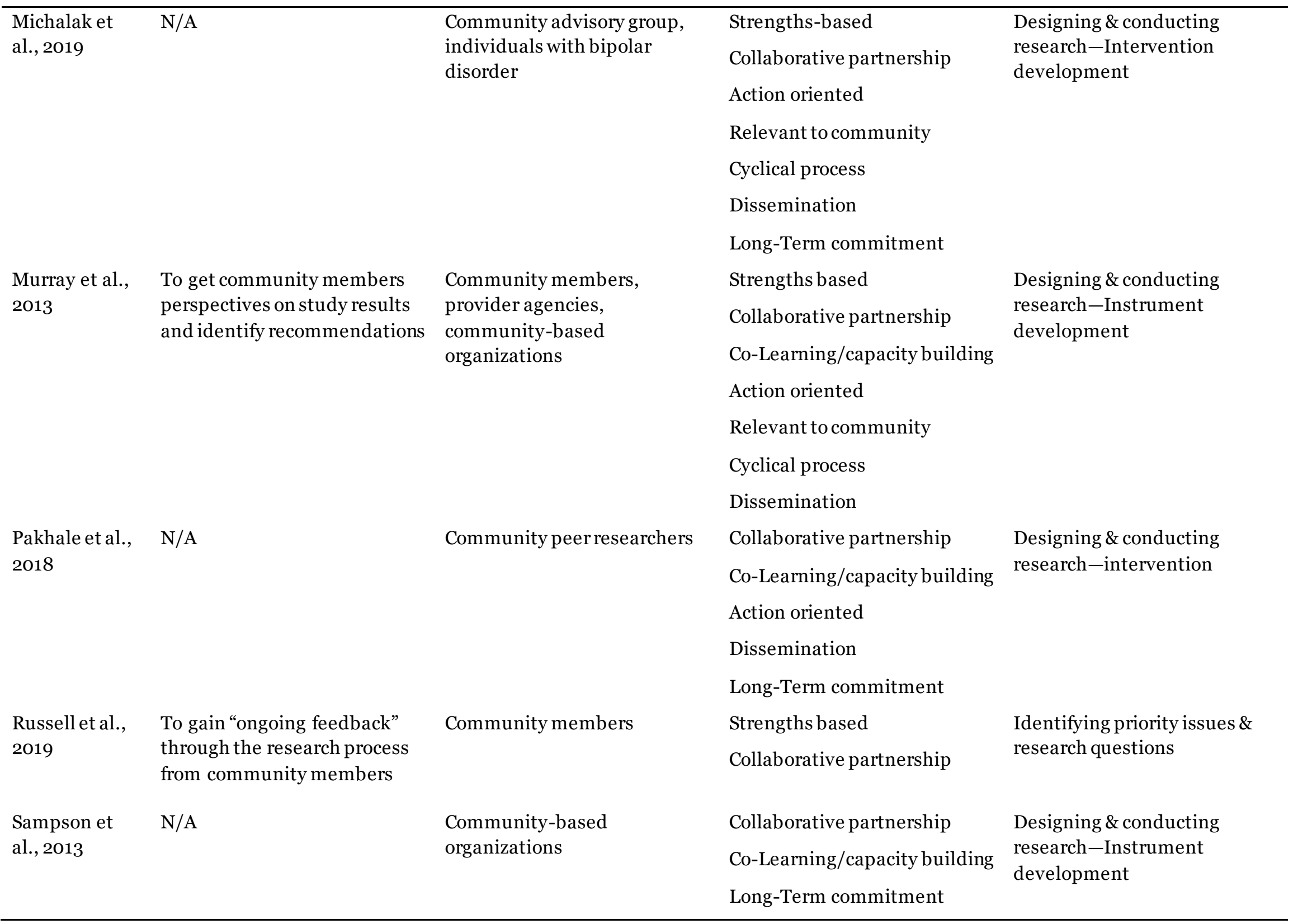




\begin{tabular}{|c|c|c|c|c|}
\hline $\begin{array}{l}\text { Shannon et } \\
\text { al., } 2016\end{array}$ & $\mathrm{~N} / \mathrm{A}$ & $\begin{array}{l}\text { Cultural leaders, physicians, } \\
\text { health department staff, } \\
\text { health plan representatives, } \\
\text { social workers, refugee } \\
\text { resettlement staff }\end{array}$ & Strengths based & $\begin{array}{l}\text { Assessing community } \\
\text { strengths \& dynamics }\end{array}$ \\
\hline $\begin{array}{l}\text { Staudt et al., } \\
2015\end{array}$ & $\begin{array}{l}\text { 1) Make use of community } \\
\text { expertise; 2) share findings for } \\
\text { dissemination and action }\end{array}$ & $\begin{array}{l}\text { Community-based } \\
\text { organization, faith-based } \\
\text { leaders }\end{array}$ & $\begin{array}{l}\text { Community defined } \\
\text { Strengths based } \\
\text { Collaborative partnership } \\
\text { Relevant to community } \\
\text { Dissemination }\end{array}$ & $\begin{array}{l}\text { Designing \& conducting } \\
\text { research-Data collection } \\
\text { (general) }\end{array}$ \\
\hline $\begin{array}{l}\text { Suchman et } \\
\text { al., } 2020\end{array}$ & $\begin{array}{l}\text { Adapt the intervention to the } \\
\text { local context and focal } \\
\text { population }\end{array}$ & $\begin{array}{l}\text { Psychosocial treatment } \\
\text { providers }\end{array}$ & $\begin{array}{l}\text { Community defined } \\
\text { Strengths based } \\
\text { Collaborative partnership } \\
\text { Co-Learning/capacity building } \\
\text { Action oriented } \\
\text { Relevant to community } \\
\text { Cyclical process } \\
\text { Long-Term commitment }\end{array}$ & $\begin{array}{l}\text { Designing and conducting } \\
\text { research-instrument } \\
\text { development }\end{array}$ \\
\hline $\begin{array}{l}\text { Vaughn et al., } \\
2013\end{array}$ & $\begin{array}{l}\text { Adapt the intervention to local } \\
\text { context and focal population }\end{array}$ & $\mathrm{N} / \mathrm{A}$ & $\begin{array}{l}\text { Strengths based } \\
\text { Action oriented } \\
\text { Relevant to community }\end{array}$ & $\begin{array}{l}\text { Designing \& conducting } \\
\text { research-Data collection } \\
\text { (general), intervention } \\
\text { development }\end{array}$ \\
\hline $\begin{array}{l}\text { Vaughn et al., } \\
2016\end{array}$ & $\mathrm{~N} / \mathrm{A}$ & Community members & $\begin{array}{l}\text { Strengths based } \\
\text { Collaborative partnership } \\
\text { Co-Learning/capacity building } \\
\text { Action oriented } \\
\text { Relevant to community }\end{array}$ & $\begin{array}{l}\text { Designing \& conducting } \\
\text { research-Data collection } \\
\text { (general), intervention } \\
\text { development }\end{array}$ \\
\hline
\end{tabular}


Cyclical process

Wood-Jaeger Adapt the intervention to the

et al., 2018 local context and focal

population
Parents, educators, social services providers, healthcare service providers
Strengths based

Collaborative partnership

Action oriented

Relevant to community

Cyclical process

Long-Term commitment
Designing and conducting research-instrument development 
Jones et al., 2020

\section{Discussion}

MMCBPR is a comprehensive research approach that is strengths-based and aims to empower marginalized, vulnerable communities by developing more relevant and sustainable solutions. By mixing quantitative and qualitative methods within the CBPR framework, practitioners and researchers in psychology and related mental health disciplines have the opportunity to maximize their ability to build more equitable communities with potential long-lasting impact. This review demonstrates how an MMCBPR approach has been used within studies related to mental health and identifies areas for improvement in future research and reporting.

The use of MMCBPR in mental health studies indicates some evidence of intersecting the two approaches. However, the deliberate use of MMR and CBPR concepts and literature could be improved. This is evidenced by the limited number of articles that provided an explicit rationale for CBPR and especially MMR. The articles that provided CBPR rationales appear to have done so in order to incorporate community experiences and expertise to create treatment and intervention programs that are more relevant to the focal population. This is not surprising given the push in recent years to address and improve client engagement (Fuertes \& Nut Williams, 2017; Holdsworth et al., 2014). Additionally, studies have shown that client engagement in treatments that honor their autonomy, lived experience, and meet expectations for what they need, improve client satisfaction and outcomes (Dearing et al., 2005; Scheel, 2011).

Although the mental health studies in this review used CBPR and show ed evidence of partnerships that integrate more community engagement than historically represented in the field, they appear to lack longterm commitment, which would allow for more rigorous study of treatments and intervention programs. This limited use of CBPR, and thus limited use of MMR within a single phase of research, further suggests an overall ad hoc intersection of MMR and CBPR to date. While this is understandable given that these types of hybrid research approaches are still budding within the field of research (DeJonckheere et al., 2018), if the field of psychology and other mental health professionals are going to advance rigorous mixed methods research approaches to comprehensively address social injustices that impact mental well-being, careful attention to strengthening the intersection of MMR and CBPR is necessary. For example, MMCBPR could contribute to more effective interventions if it were more frequently used to identify community strengths, needs, and priorities prior to intervention development.

\section{Limitations}

Through this review we aim to advance the use of MMCBPR in mental health studies by applying a critical lens to existing empirical articles. Our approach has several limitations. First, the typical academic journal format and length allowed for a manuscript may influence what content is included in a publication and therefore limit our understanding and evaluation of each study. Although MMR and CBPR can often be described to the extent in which other methodologies and research designs are presented in typi cal journal articles, the descriptions of MMR and CBPR components and processes could take up an entire article of their own.

Second, we operationalized each article as its own study and excluded related articles that extended into multiple publications (e.g., one study manuscript published quantitative results and a follow-up manuscript focused on the qualitative results). In these cases, study authors may consider each method and findings to be part of one larger study, but if both were not represented in a single article, MMR integration could not be reviewed.

Third, we limited this review to the CBPR approach because of its prominence in the mental health literature and recommendations to explore MMCBPR in different fields; however, there are other act ion and 
participatory research approaches that can be intersected with MMR (e.g., Ivankova, 2014; Ivankova \& Wingo, 2018) and should be examined in future reviews to fully understand the field.

\section{Improving the Intersection of MMR and CBPR in Mental Health Studies}

Despite the limitations within this review and the use of MMCBPR to date, the increasing use and relevance of MMR and CBPR and the potential power of intersecting the two approaches in psychological research warrants practical guidance for using the innovative yet complex methodological approach. The recommendations below aim to use the findings from this review to (1) advance the agenda of social justice and critical inquiry within the mental health field and (2) increase intentionality around the combination of MMR and CBPR approaches in mental health studies. The following sections describe a set of MMCBPR practices derived from one or more of the seven phases ofCBPR described by Israel and colleagues (2013), indicated in brackets.

Gather a diverse team to build equity in the MMR design [Forming a CBPR partnership]. A central feature of any MMCBPR project should be commitment to and focus on relationships between community and academic partners. A key principle of CBPR is equitable research partnerships across all phases (Israel et al., 2013). CBPR partnerships require equitable community-academic research partnerships to help all stakeholders benefit from knowledge gained about a given topic. To incorporate MMR in this initial phase of CBPR, academic partners should consider what type of methodological expertise is needed to conduct an MMR study. Researchers should also consider what kind of training and dialogues are needed for both community members and academic partners to actualize the benefits of MMR as a means to improve individual and community well-being.

Incorporate MMR into the assessment of community strengths and resources to develop research questions that are meaningful to community partners [Assessing community strengths and dynamics; identifying priority issues].

This phase of MMCBPR can serve as a first iteration of a long-term research partnership and a potential multiphase MMR design focused on mental wellness. The assessment should center on identifying concerns and unmet needs that are relevant to the focal population. These should then inform research questions that, when answered, can generate solutions for the identified issues. Incorporating questions that can be answered through mixed methods provides the opportunity to understand a problem across a broader sample of the population (quantitative) and through rich descriptions of the local context to better inform viable solutions (qualitative). MMR best practices also necessitate a question that focuses on how the data collection methods will be integrated (Creswell \& Plano Clark, 2018; Plano Clark \& Ivankova, 2011) to inform the mental health issue being studied. All CBPR team members should review possible quantitative and qualitative methods to select those that will best answer the research questions and be acceptable for the focal population.

\section{Develop an MMCBPR rationale for answering the identified research questions. [Designing and conducting research].}

An MMCBPR rationale serves as a roadmap to the process of co-creating knowledge that benefits communities. It also provides a clear understanding of how MMR and CBPR intersect in a study in order to strengthen the empirical evidence produced within mental health. Inclusion of an MMCBPR rationale in written proposals and research manuscripts can help readers and reviewers assess the value added by the selected approach, which is necessary for expanding MMCBPR within mental health studies. It is also necessary so that other researchers and communities may use or replicate MMCBPR designs in their own studies. The rationale should include an MMR rationale and a CBPR rationale (DeJonckheere et al., 2018), as well as a description of how the two intersect within the study to contribute to mental health research.

As part of identifying the priority issues and research questions, an MMR rationale can inform the type of MMR design to be used and explain the benefits of the design. Examples of MMR rationales identified and 
Jones et al., 2020

described in the scholarly literature include triangulation, complementarity, intervention development, offsetting weaknesses present in quantitative and qualitative methods alone, and promotion of social justice (see Bryman, 2006; Creswell \& Plano Clark, 2018; Plano Clark \& Ivankova, 2016). This lite rature should be consulted and cited when developing the MMR rationale.

Of the CBPR rationales identified in the current review, most describe incorporating community experiences and expertise to create programs that are more relevant to the focal populations. This indicates that the field is interested in research that better aligns with community needs and has made some strides in producing research that at least indirectly questions traditional academic-driven paradigms. That being said, additional exploration of rationales for using CBPR in mental health and related studies would help advance MMCBPR literature within this field of study.

\section{Describe how the selected MMR design contributes to the aims of the CBPR partnership [Designing and conducting research].}

The local context, research questions, and MMCBPR rationale should inform the MMR design. To ensure the intersection of MMR and CBPR is intentional and thorough, practitioners should describe how the use of MMR contributes to the broader goals of the CBPR partnership and furthers their work together. Additionally, study authors should state how this intersection benefits mental health research. For example, in studying the effectiveness of a new intervention developed by CBPR partners, a convergent de sign may be selected to quantitatively measure the impact of the program on individuals and qualitatively examine how the intervention has been implemented within a practice setting. The integration of methods in this example could contribute to the partnership by allowing them to assess their co-created intervention and determine next steps for applying the findings in the local setting, but it also can contribute to the mental health literature about potential effective interventions.

\section{Utilize the expertise of CBPR partners to conduct the MMCBPR study. [Designing and conducting research].}

An ideal CBPR partnership incorporates community members throughout all phases of a research project and does not limit them to being external advisors to a research study conducted by academics. MMR studies are complex in their own right, with investigators having tojuggle multiple components and potentially long timelines to execute the selected design. Integrating community members in the research design, participant recruitment, and data collection may not only alleviate the constraints many researchers face in reaching out to participants but utilizing their lived experience can enhance the rigor of the study (Balasz \& MorelloFrosch, 2013; Vaughn et al., 2018). Studies focused on sensitive topics, such as mental health, may benefit from designs grounded in experiences of members from the target community and data collectors whom participants consider relatable and trustworthy as a means to improve response rates and obtain more detailed qualitative responses that contribute to the reliability of the study.

\section{Collaborate with community partners for interpretation of MMR findings [Feeding back and interpreting research findings].}

CBPR is an approach that aims to engender equality. By including community partners, it allows for a more robust and relevant interpretation of the findings leading to community action and change. This enhanced interpretation can be, in part, attributed to the diversity of interpreters, including the view from academia as well as those directly impacted by the phenomenon under investigation. Community strengths are placed in the forefront when interpreting the MMR qualitative and quantitative data streams and increase the potential to inform the social action aspects of CBPR. MMCBPR allows the interpretation of findings to be a place where those who historically have been marginalized in the research process are given meaning, power, voice, decision-making, and leadership. For example, Dickerson et al. (2014) investigated substance abuse in American Indians/Alaska Native (AI/AN) and the intervention of Drum-Assisted Recovery therapy. The research team (2014) developed a community advisory board (CAB), which included leaders, elders, and 
Jones et al., 2020

drummers in the Los Angeles AI/AN community. During the qualitative stage, the CAB members attended the focus groups, providing input along with interpretation that assisted in the development of community -driven strategies and themes. By collaborating closely with com munity partners, MMCBPR has the potential to bring about transparency, justice, and community capacity within the research process, thus removing barriers for improved mental health.

\section{Share MMR findings with diverse audiences for practice and community change [Disseminating and translating research findings].}

Historically, there has been a gap in the dissemination and implementation of effective mental health interventions and practices; however, CBPR has been identified as a poignant strategy for improving the uptake of these within communities (Mendel et al., 2008). Although a key principle of CBPR is disseminating findings to all community partners and involving partners in the wider dissemination of findings in order to promote change, there was often a lack of explicit explanation of dissemination of findings beyond the academic journal within the studies included in our review. Moreover, when community dissemination was described, the text was often obscure and lacked clarity. A benefit of MMCBPR is having both the numbers and the stories to make the findings more compelling and translatable to diverse audiences, including those who can directly impact mental health, such as peers and community leaders, mental health providers, policymakers, and funders. In one exemplary study from our review, Bell and colleagues (2014) used community forums, discussion panels, social media via their $\mathrm{CAB}$, and cultural enrichment programs as a way to disseminate information on suicide within the Lumbee youth. Future MMCBPR studies in mental health would benefit from consideration of community-academic dissemination strategies early in the process and clearly articulate the employed strategies in study publications.

\section{Using MMR to strengthen CBPR partnerships [Maintaining, sustaining, and evaluating a CBPR partnership].}

CBPR projects should seek to benefit all stakeholders by offering a balance between research agenda and action that benefits the community (Israel et al., 2013). The pragmatic and dialectical philosophical underpinnings of MMR (Greene \& Hall, 2010) complement and provide a methodological framework for implementing this major tenet of CBPR. Just as CBPR has the potential to improve the execution of MMR, MMR offers a comprehensive approach to furthering the aims of CBPR. That said, none of the studies in this review specifically used MMR to maintain, sustain, or evaluate the CBPR partnership, although a few studies showed long-term commitment to the partnership (Bell et al., 2014; Berkel et al., 2013; Campbell et al., 2014; Conway et al., 2017; Marlow et al., 2015; Sampson et al., 2013). As the field of mental health continues to push for meaningful engagement of individuals and families in research and service provision, MMR can be incorporated to ensure that these partnerships are understood and supported in order to fully actualize community change.

\section{Conclusion}

Our findings indicate that MMCBPR studies are being used to examine research questions related to mental health and well-being. This aligns with the field's focus on interventions that are relevant to the focal population and the use of comprehensive research designs that allow for process and outcomes evaluation. In order to effectively leverage the aims of both mixed methods research and community-based participatory designs, researchers should intentionally consider the varied ways in which MMR and CBPR can be intersected. MMCBPR projects require negotiating roles for community and academic partners and identifying specific ways that community partners can be involved throughout the research process, including contributions to the conceptualization, design, data collection, analysis, and dissemination phases. Though the lived experience and expertise community partners' offer is essential to intervention development, we recommend that mental health researchers, practitioners, and students from a variety of fields consider how 
they can use MMCBPR more frequently to identify community strengths, needs, and priorities prior to intervention development and implementation. Additionally, given the inherent complexities of MMR studies in mental health, there is room to use MMCBPR in the interpretation of results to improve interventions, program delivery, and the effects on individuals and families. The eight MMCBPR best practices developed as a result of this methodological review can be used to promote social justice and positive change to improve mental health and well-being. 


\section{References}

Allen, M. L., Hurtado, G. A., Yon, K. J., Okuyemi, K. S., Davey, C. S., Marczak, M. S., Stoppa, P., \& Svetaz, V. M. (2013). Feasibility of a parenting program to prevent substance use among Latino youth: A community-based participatory research study. American Journal of Health Promotion, 27(4), 240244.

American Psychiatric Association. (2017). Mental health disparities: Diverse populations. https://www.psychiatry.org/psychiatrists/cultural-competency/education/mental-health-facts

Anderson-Lewis, C., Cuy-Castellanos, D., Byrd, A., Zynda, K., Sample, A., Blakely Reed, V., Beard, M., Minor. L., \& Yadrick, K. (2012). Using mixed methods to measure the perception of community capacity in an academic-community partnership for a walking intervention. Health Promotion Practice, 13(6), $788-$ 796.

Badiee, M., Wang, S., \& Creswell, J. W. (2012). Designing community-based mixed methods research. In D. K. Nagata, L. Kohn-Wood, \& L. A. Suzuki (Eds.), Qualitative strategies for ethnocultural research (pp. 41-59). American Psychological Association.

Balasz, C. L., \& Morello-Frosch, R. (2013). The three Rs: how community-based participatory research strengthens the rigor, relevance, and reach of science. Environmental Justice, 6(1), 9-16.

Bell, R., Arnold, E., Golden, S., Langdon, S., Anderson, A., \& Bryant, A. (2014). Perceptions and psychosocial correlates of bullying among Lumbee Indian youth. American Indian and Alaska Native Mental Health Research (Online), 21(1), 1-7. 10.5820/aian.2101.2014.1

Berkel, C., McBride Murry, V., Roulston, K. J., \& Brody, G. H. (2013). Understanding the art and science of implementation in the SAAF efficacy trial. Health Education, 113(4), 297-323. https://doi.org/10.1108/09654281311329240

Blitz, L. V., Anderson, E. M., \& Saastamoinen, M. (2016). Assessing perceptions of culture and trauma in an elementary school: Informing a model for culturally responsive trauma-informed schools. Urban Review, 48(4), 520-542. https://doi.org/10.1007/s11256-016-0366-9

Bryman, A. (2006). Integrating quantitative and qualitative research: How is it done? Qualitative Research, 6(1), 97-113. https://doi.org/10.1177/1468794106058877

Campbell, A. N., Turrigiano, E., Moore, M., Miele, G. M., Rieckmann, T., Hu, M. C., Kropp, F., Ringor-Carty, R., \& Nunes, E. V. (2015). Acceptability of a web-based community reinforcement approach for substance use disorders with treatment-seeking American Indians/Alaska Natives. Community Mental Health Journal, 51(4), 393-403. https://doi.org/10.1007/s10597-014-9764-1

Carvajal, S. C., Rosales, C., Rubio-Goldsmith, R., Sabo, S., Ingram, M., McClelland, D. J., Redondo, R., Torres, E., Romero, A. J., O’Leary, A. O., Sanchez, A., \& Guernsey de Zapien, J. (2013). The border community and immigration stress scale: A preliminary examination of a community responsive measure in two southwest samples. Journal of Immigrant and Minority Health, 15(2), 427-436. https://doi.org/10.1007/s10903-012-9600-z

Conway, P., Favet, H., Hall, L., Uhrich, J., Palche, J., Olimb, S., Tesch, N., York-Jesme, M., \& Bianco, J. (2016). Rural health networks and care coordination: Health care innovation in frontier communities to improve patient outcomes and reduce health care costs. Journal of Health Care for the Poor and Underserved, 27(4A), 91-115. https://doi.org/10.1353/hpu.2016.0181

Creswell, J. W., Klassen, A. C., Plano Clark, V. L., \& Smith, K. C. (2011). Best practices for mixed methods research in the health sciences. National Institutes of Health, 2094-2103. 
Creswell, J. W. (2015). Educational research: Planning, conducting, and evaluating quantitative and qualitative Research. Pearson Education, Inc.

Creswell, J. W. \& Plano Clark, V. L. (2018). Designing and conducting mixed methods research (3rd ed.). Sage.

Christ, T. W. (2013). The worldview matrix as a strategy when designing mixed methods research. International Journal of Multiple Research Approaches, 7(1), 110-118. http://doi.org/10.5172/mra.2013.7.1.110

Dearing, R. L., Barrick, C., Dermen, K. H., \& Walitzer, K. S. (2005). Indicators of client engagement: Influences on alcohol treatment satisfaction and outcomes. Psychology of Addictive Behaviors, 19(1), 71.

DeJonckheere, M., Lindquist-Grantz, R., Toraman, S., Haddad, K., \& Vaughn, L. M. (2018). Intersection of mixed methods and community-based participatory research: A methodological review. Journal of Mixed Methods Research, 13(4), 481-502. https://doi.org/10.1177/1558689818778469

Dickerson, D. L., Venner, K. L., Duran, B., Annon, J. J., Hale, B., \& Funmaker, G. (2014). Drum -assisted recovery therapy for Native Americans (DARTNA): Results from a pretest and focus groups. American Indian and Alaska Native Mental Health Research (Online), 21(1), 35-58. 10.5820/aian.2101.2014.35

Fetters, M. D., Curry, L. A., \& Creswell, J. W. (2013). Achieving integration in mixed methods designs Principles and practices. Health Services Research, 48(6pt2), 2134-2156. https://doi.org/10.1111/1475-6773.12117

Ferguson, K. M. (2012). Merging the fields of mental health and social enterprise: Lessons from abroad and cumulative findings from research with homeless youths. Community Mental Health Journal, 48(4), 490-502. https://doi.org/10.1007/s10597-011-9440-7

Fine, M. (2007). Expanding the methodological imagination. The Counseling Psychologist, 35(3), 459-473. https://doi.org/10.1177/0011000006296172

Fuertes, J. N., \& Nutt Williams, E. (2017). Client-focused psychotherapy research. Journal of Counseling Psychology, 64(4), 369. https://doi.org/10.1037/couo000214

Gelso, C. J. (1979). Research in counseling: Methodological and professional issues. The Counseling Psychologist, 8, 7-36.

Goodyear-Smith, F., Corter, A., \& Suh, H. (2016). Electronic screening for lifestyle issues and mental health in youth:A community-based participatory research approach. BMC Medical Informatics and Decision Making, 16(1), 1-8. https://doi.org/10.1186/s12911-016-0379-Z

Hanson, W. E., Creswell, J. W., Plano Clark, V. L., Petska, K. S., \& Creswell, J. D. (2005). Mixed methods research designs in counseling psychology. Journal of Counseling Psychology, 53(2), 224-235. https://doi.org/10.1037/0022-0167.52.2.224

Hanssmann, C., Morrison, D., \& Russian, E. (2008). Talking, gawking, or getting it done: Provider trainings to increase cultural and clinical competence for transgender and gender-nonconforming patients and clients. Sexuality Research \& Social Policy, 5(1), 5-23. https://doi.org/10.1525/srsp.2008.5.1.5

Haverkamp, B. E., Morrow, S. L., \& Ponterotto, J. G. (2005). A time and place for qualitative and mixed methods in counseling psychology research. Journal of Counseling Psychology, 52(2), 123-125. 10.1037/0022-0167.52.2.123

Hoffmann, K. D., Walnoha, A., Sloan, J., Buddadhumaruk, P., Huang, H.-H., Borrebach, J., Cluss, P. A., \& Burke, J. G. (2015). Developing a community-based tailored exercise program for people with severe and persistent mental illness. Progress in Community Health Partnerships: Research, Education, and Action, 9(2), 213-227. https://doi.org/10.1353/cpr.2015.0045 
Jones et al., 2020

Holdsworth, E., Bowen, E., Brown, S., \& Howat, D. (2014). Client engagement in psychotherapeutic treatment and associations with client characteristics, therapist characteristics, and treatment factors. Clinical Psychology Review, 34(5), 428-450.

Israel, B. A., Eng, E., Schulz, A. J., \& Parker, E. A. (2013). Introduction to methods for CBPR for health. In B. A. Israel, A. J. Schulz \& E. A. Parker (Eds.), Methods for community-based participatory research for health. Jossey-Bass.

Ivankova, N. V. (2014). Mixed methods applications in action research: From methods to community action. Sage Publications.

Ivankova, N., \& Wingo, N. (2018). Applying mixed methods in action research: Methodological potentials and advantages. American Behavioral Scientist, 62(7), 978-997. https://doi.org/10.1177/0002764218772673

Johnson, B., \& Turner, L. A. (2003). Data collection strategies in mixed methods research. In A. Tashakkori \& C. Teddlie (Eds.), Handbook of mixed methods in social \& behavioral research (pp. 297-319). Sage Publications.

Johnson, C. E., Ali, S. A., \& Shipp, M. P. L. (2009). Building community-based participatory research partnerships with a Somali refugee community. American Journal of Preventive Medicine, 37(6), S230-S236. 10.1016/j.amepre.2009.09.036

Jones, D. E., Tang, M., Folger, A., Ammerman, R. T., Hossain, M. M., Short, J. A., \& Van Ginkel, J. B. (2018). Neighborhood effects on PND symptom severity for women enrolled in a home visiting program. Community Mental Health Journal, 54(4), 420-428. 10.1007/s10597-017-0175-y

Jumper-Reeves, L., Dustman, P. A., Harthun, M. L., Kulis, S., \& Brown, E. F. (2014). American Indian cultures: How CBPR illuminated intertribal cultural elements fundamental to an adaptation effort. Prevention Science, 15(4), 547-556. https://doi.org/10.1007/s11121-012-0361-7

Lake, J., \& Turner, M. S. (2017). Urgent need for improved mental health care and a more collaborative model of care. The Permanente Journal, 21, 17-24. https://doi.org/10.7812/TPP/17-024

Livingston, J. D., Desmarais, S. L., Verdun-Jones, S., Parent, R., Michalak, E., \& Brink, J. (2014). Perceptions and experiences of people with mental illness regarding their interactions with police. Theoretical and Applied Climatology, 37, 334-340. https://doi.org/10.1016/j.ijlp.2014.02.003

Lucero, J., Wallerstein, N., Duran, B., Alegria, N., Greene-Moton, E., Israel, B., Kastelic, S., Magarati, M., Oetzel, J., Pearson, C., Schulz, A., Villegas, M., \& Whitehat, E.R. (2018). Development of mixed methods investigation of process and outcomes of community-based participatory research. Journal of Mixed Methods Research, 12(1), 55-74. https://doi.org/10.1177/1558689816633309

Palinkas, L. A., Horwitz, S. M., Chamberlain P., Hurlburt, M. S., \& Landsverk J. (2011). Mixed-methods designs in mental health services research: A review. Psychiatric Services, 62(3), 255-263. https://doi.org/10.1176/ps.62.3.pss6203 0255

Plano Clark, V. L., \& Ivankova, N. V. (2016). Mixed methods research: A guide to the field. Sage.

Marlow, E., Grajeda, W., Lee, Y., Young, E., Williams, M., \& Hill, K. (2015). Peer mentoring for male parolees: A CBPR pilot study. Progress in Community Health Partnerships: Research, Education, and Action, 9(1), 91-100. 10.1353/cpr.2015.0013

Mendel, P., Meredith, L. S., Schoenbaum, M., Sherbourne, C. D., \& Wells, K. B. (2008). Interventions in organizational and community context: A framework for building evidence on dissemination and implementation in health services research. Administration and Policy in Mental Health and Mental Health Services Research, 35(1-2), 21-37. https://doi.org/10.1007/s10488-007-0144-9 
Mertens, D. M., Bazeley, P., Bowleg, L., Fielding, N., Maxwell, J., Molina-Azorin, J. F., \& Niglas, K. (2016). The future of mixed methods: A five year projection to 2020. Mixed methods international research association.

https://mmira.wildapricot.org/resources/Documents/MMIRA\%20task\%2oforce\%2oreport\%20Jan2 016\%20final.pdf

Michalak, E. E., Livingston, J. D., Maxwell, V., Hole, R., Hawke, L. D., \& Parikh, S. V. (2014). Using theatre to address mental illness stigma: Knowledge translation study in bipolar disorder. International Journal of Bipolar Disorders, 2(1), 1-12. https://doi.org/10.1186/2194-7511-2-1

Minkler, M., \& Wallerstein, N. (2008). Community-based participatory research for health: From process to outcomes. Jossey-Bass.

Murray, L. K., Dorsey, S., Skavenski, S., Kasoma, M., Imasiku, M., Bolton, P., Bass, J., \& Cohen, J. A. (2013). Identification, modification, and implementation of an evidence-based psychotherapy for children in a low-income country: The use of TF-CBT in Zambia. International Journal of Mental Health Systems, 7(24), 1-12. https://doi.org/10.1186/1752-4458-7-24

National Center for Health Statistics. (2018). QuickStats: Age-adjusted suicide rates, by race/ethnicitynational vital statistics system, United States, 2015-2016. MMWR Morbidity and Mortality Weekly Report, 67(14). http://dx.doi.org/10.15585/mmwr.mm6714a6

Sampson, N. R., Parker, E. A., Cheezum, R. R., Lewis, T. C., O’Toole, A., Zuniga, A., Robbins, T. G., \& Keirns, C. C. (2013). "I wouldn't look at it as stress": Conceptualizations of caregiver stress among low-income families of children with asthma. Journal of Health Care for the Poor and Underserved, 24, 275288. https://doi.org/10.1353/hpu.2013.0021

Scheel, M. J. (2011). Client common factors represented by client motivation and autonomy. The Counseling Psychologist, 39(2), 276-285. https://doi.org/10.1177/0011000010375309

Scheel, M. J., Stabb, S. D., Cohn, T. J., Duan, C., \& Sauer, E. M. (2018). Counseling psychology model training program. The Counseling Psychologist, 46(1), 6-49. https://doi.org/10.1177/0011000018755512

Shannon, P. J., Vinson, G. A., Cook, T. L., \& Lennon, E. (2016). Characteristics of successful and unsuccessful mental health referrals of refugees. Administration and Policy in Mental Health and Mental Health Services Research, 43(4), 555-568. https://doi.org/10.1007/s10488-015-0639-8

Silva, M., Loureiro, A., \& Cardoso, G. (2016). Social determinants of mental health: A review of evidence. European Journal of Psychiatry, 30 (4).

Staudt, K., Dane'El, M., \& Márquez-Velarde, G. (2015). In the shadow of a steel recycling plant in these neoliberal times: Health disparities among Hispanics in a border colonia. Local Environment, 21(5), 636-652. https://doi.org/10.1080/13549839.2015.1016902

Teddlie, C., \& Tashakkori, A. (2009). Foundations of mixed methods research: Integrating quantitative and qualitative approaches in the social and behavioral sciences. Sage Publications.

Vaughn, L. M., Jacquez, F., \& McLinden, D. (2013). The use of concept mapping to identify community -driven intervention strategies for physical and mental health. Health Promotion Practice, 14(5), 675-685. https://doi.org/10.1177/1524839912462871

Vaughn, L. M., Jacquez, F., Marschner, D., \& McLinden, D. (2016). See what we say: Using concept mapping to visualize Latino immigrant's strategies for health interventions. International Journal of Public Health, 61(7), 837-845. https://doi.org/10.1007/s00038-016-0838-4

Vaughn, L. M., Jacquez, F., Lindquist-Grantz, R., Parsons, A., \& Melink, K. (2017). Immigrants as research partners: A review of immigrants in community-based participatory research (CBPR). Journal of Immigrant and Minority Health, 19(6), 1457-1468. 
Vaughn, L. M., Whetstone, C., Boards, A., Busch, M. D., Magnusson, M., \& Määttä, S. (2018). Partnering with insiders: A review of peer models across community-engaged research, education and social care. Health \& Social Care in the Community, 26(6), 769-786. https://doi.org/10.1111/hsc.12562

Windsor, L. C. (2013). Using concept mapping in community-based participatory research: A mixed methods approach. Journal of Mixed Methods Research, 7(3), 274-293. 10.1177/1558689813479175

Whiteford, H. A., Degenhardt L., Rehm J., Baxter A. J., Ferrari A. J., Erskine H. E., Charlson, F. J., Norman, R. E., Flaxman, A. D., Johns, N., Burstein, R., Murray, C. J. L., \& Vos, T. (2010). Global burden of disease attributable to mental and substance use disorders: Findings from the Global Burden of Disease Study 2010. Lancet. 2013, 382(9904), 1575-1586. https://doi.org/10.1016/So140-6736(13)61611-6

The Journal of Social, Behavioral, and Health Sciences (JSBHS), co-sponsored by the College of Health Sciences and the College of Social and Behavioral Sciences at Walden University, is a peer-reviewed, online, interdisciplinary journal focusing on theoretically-based research that addresses contemporary national and international issues. $J S B H S$ articles include peer-reviewed research reports, brief reports, comprehensive literature reviews, books reviews, and student research 